NBER WORKING PAPERS SERIES

CROSS-COUNTRY PATTERNS OF CHANGE IN RELATTVE WAGES

Steven J. Davis

Working Paper No. 4085

NATIONAL BUREAU OF ECONOMIC RESEARCH

1050 Massachusetts Avenue

Cambridge, MA 02138

June 1992

Prepared for the 1992 NBER Macroeconomics Annual, edited by Olivier Blanchard and Stanley Fischer. For helpful conversations and comments on a previous draft, I extend my thanks to Olivier Blanchard, Per-Anders Edin, Richard Freeman, Larry Katz, Catherine Mann, Kevin Murphy, participants in the Macro Annual conference and workshop participants at the Universities of Chicago and Maryland. I also extend my thanks to Per-Anders Edin, Claudia Goldin, Larry Katz, Dae Il Kim, David Lam, Juan Londono, Gary Loveman, Kevin Murphy, Karen Needels, and Mark Rebick for kindly supplying data, not all of which is used in this paper. Tonia Davis and Ngan Dao provided valuable research assistance. This paper is part of NBER's research programs in Economic Fluctuations and Labor Studies. Any opinions expressed are those of the author and not those of the National Bureau of Economic Research. 
NBER Working Paper \#4085

June 1992

\title{
CROSS-COUNTRY PATTERNS OF CHANGE IN RELATIVE WAGES
}

\begin{abstract}
This paper investigates movements in relative wages and wage inequality across thirteen of the world's major economies. Focusing on wages received by full-time male workers, the investigation uncovers several empirical regularities: (1) Most advanced industriallzed economies show increases, often large, in wage inequality during the 1980s; none show declining wage inequality. In contrast, three of four middle income countries considered here show sharply declining wage inequality during the 1980s. (2) Since the early to late 1970s, the advanced economies show large and persistent increases in the wages of prime age men relative to the wages of less experienced men. (3) Following a period of sharply declining education differentials in the 1970s, the advanced economies show rising or flat education differentials after 1980 . Education differentials fell moderately to sharply in the middle income countries during the 1980s. (4) Wage inequality among obscrvationally similar workers rose sharply during the 1980 s in most advanced economies. (5) After 1975, the structure of relative industry wages in the manufacturing sector became increasingly dissimilar across the advanced economies. However, controlling for common time effects, increases in intemational trade as a fraction of GDP are associated with a partal convergence of relative industry wage structures across countries. The paper discusses several altemative interpretations of wage structure developments in the United States and other countries in the light of these empirical regularities.
\end{abstract}

Steven J. Davis

Graduate School of Business

University of Chicago

1101 East 58th Sureet

Chicago, IL 60637

and NBER

and Federal Reserve Bank of Chicago 


\section{Introduction}

The U.S. economy underwent pronounced shifts in key aspects of its relative wage structure in recent decades and sharp increases in overall wage inequality during the $1980 \mathrm{~s}$. Education differentials fell sharply in the 1970s but then rose even more sharply in the 1980s. Experience differentials also rose over the past two decades, especially for less educated workers. Inequality among workers with similar observational characteristics as reflected in sex, education and potential experience - rose steadily and substantially after 1970 (Juhn, Murphy and Pierce, 1991). By the end of the 1980s, these developments had pushed overall U.S. earnings inequality to a level not seen since 1939 (Goldin and Margo, 1992).

An outpouring of recent research carefully documents these developments and endeavors to discriminate among competing explanations for the observed changes. Goldin and Margo (1992) and Katz and Murphy (1992) provide two of the more comprehensive analyses of major changes in the wage structure during recent decades. Levy and Murnane (1992) provide an extensive survey of the literature. Many authors in this literature stress that the absence of long-term real wage growth since the early 1970 s implies large real wage declines for less-educated younger men and other workers who are most adversely affected by recent changes in the relative wage structure. Gottschalk and Moffitt (1992) provide evidence that the greater spreading of cross-sectional wage distributions documented by many researchers primarily reflects increased inequality in the permanent component of worker earnings. Cutler and Katz (1992) report that movements in overall U.S. income and consumption inequality during the 1980s parallel the sharp rise in earnings inequality.

Most analyses of wage structure developments focus on a single country, but a handful of recent studies compare movements in relative wages across two or more countries. Multicountry studies represent a potentially powerful tool for discriminating among competing explanations of relative wage developments and for identifying the causal component of institutional changes and government interventions. Multi-country studies also serve as useful inputs into detailed studies on individual countries by suggesting when to pursue explanations that stress factors common to many countries and when to pursue explanations that stress country-specific factors. Multi-country studies are also likely to highlight certain hypotheses or suggest additional explanations that fail to surface in studies on particular countries.

Motivated by these considerations, Katz and Revenga (1989) compare relative wage movements between Japan and the United States; Blackburn and Bloom (1990) compare changes in family earnings inequality across Australia, Canada, and the United States; 
Freeman and Veedels (1991) compare relative wage movements between Canada and the Cnited States: Katz and Loveman (1000) investigate relative wage movements in France, the United Kingdom and the United States: Freeman (1991) considers the role of unions in mediating relative labor demand disturbances across several countries; and Gottschalk and Joyce (1091) investigate relative wage movements during the 1980s in several advanced economies.

This paper also examines relative wage developments across many countries. The main contribution of the paper is a careful description of changes in the structure of wages in nine advanced economies - the United States, Japan, United Kingdom, France, Sweden. Canada, West Germany, Australia, and the Netherlands - and four middle income economies - Brazil. Colombia. South Korea and Venezuela. Focusing on full-time men, the paper examines changes in four aspects of the wage structure: overall earnings inequality, education differentials. experience and age differentials, and earnings inequality among men with similar levels of experience and education. Drawing on a broader sample of twentyfour countries. the paper also investigates whether the structure of relative industry wages in the manufacturing sector has become more or less uniform across countries over time.

\section{Wain Emptrical Findings}

The main empirical regularities uncovered by the descriptive analysis can be grouped as follows:

1. Trends in Overall Wage Inequality: Rising wage inequality during the 1980 s is a common. though not universal, phenomenon among the advanced economies. In several advanced economies. the surge in overall wage inequality during the 1980s appears comparable in magnitude to the U.S. experience. No advanced economies show declining wage inequality during the 1080s. In contrast, three of four middle income economies considered here show sharply declining wage inequality during the 1970s and 1980s.

2. Structure of Wage Inequality: There are remarkably large differences in the structure of wage inequality across the advanced economies, as reflected by cross-country differences in the relative spread over the upper and lower halves of the wage distribution. The ratio of the 90-50 to the 50-10 log wage differentials in France exceeds twice the corresponding ratio in Canada and the United States. In stark contrast to other advanced economies. the bottom half of the French wage distribution became more compressed in the late 1070s and 1050s. These features of the French wage structure and distinctive aspects of the Swedish experience point to wage-setting institutions and government labor market interventions as potentially powerful influences on earnings inequality. 
3. Movements in Education Differentals: Among advanced economies, the 1970s saw widespread and frequently sharp declines in education differentials. This pattern shifted around 1980 to one of flat or rising education differentials among all advanced economies in the sample except the Netherlands. Among middle income countries, education differentials fell moderately to sharply during the 1980 s.

4. Rising Experience Differentials: All advanced economies in the sample except Sweden show strong and persistent increases in the wage differential between prime age and younger men during the 1980s. Where data are available, rising returns to experience typically date back to the middle 1970 s or earlier. Increases in age-earnings differentials are more pronounced and more persistent for less educated men.

5. Rising Inequality Among Observationally Similar Workers: In most advanced economies, wage inequality among men with similar levels of education and experience rose sharply during the 1980s. In contrast, three of four middle income economies show sharply declining within-group wage inequality over the same time span.

6. Divergence of Relative Industry Wage Structures: Contrary to the predictions of a simple factor proportions theory, the structure of relative industry wages in the manufacturing sector became increasingly dissimilar across countries between 1975 and 1989 . The divergence is concentrated in the interval from 1976 to 1982 . However, controlling for common year effects, an increase in international trade as a fraction of gross domestic product is associated with the partial convergence of a country's relative industry wage structure to the worldwide average structure. This finding confirms a prediction of the factor proportions theory, and it indicates that the overall divergence of relative industry wage structures reflects some unobserved force that more than offsets the convergence-inducing effects of greater international trade.

The remainder of the paper is organized as follows. Section 2 describes the measurement strategy and the data. Subsequent sections investigate movements in overall wage inequality, education differentials, age differentials, and within-group wage inequality. These sections provide a guided tour through the key cross-country empirical regularities related to relative worker wages. Along the way, I introduce and discuss many of the hypotheses regarding relative wage movements that have received attention in the literature. Section 7 turns to relative industry wages. The analysis first develops various hypotheses related to the idea that reduced barriers to international trade induce a partiai convergence of relative shill prices and relative industry wages across countries. I then test partial convergence hypotheses that involve relative industry wages. Section 8 offers brief concluding remarks. 


\section{Remarks on the Empirical Strategy and the Data}

$A$ key objective of the empirical investigation is to measure relative wage changes within each country for groups of workers that maintain a reasonably constant composition over time. Controlling for compositional changes enables one to discern changes in relative wages between and within groups of workers who maintain a fixed set of characteristics. Since female employment rates change dramatically over the sample period in many countries, it is difficult to achieve consistency across countries and over time in controls for women's labor market experience. Primarily for this reason, I focus on relative wage changes for men. ${ }^{1}$

As a related consideration, the extent of part-time and part-year employment is likely to vary through time in different ways for different types of workers. These differences can seriously distort measures of relative wage changes based on, say, annual earnings among all workers with positive earnings, because they confuse changes in relative prices per unit of labor services with changes in relative hours worked. To minimize this problem, I typically focus on the wage behavior of full-time male wage earners who evince a strong attachment to the work force. Selection criteria typically encompass men who work a minimum number of weeks or hours in the pay period, and who earn the bulk of labor income from wages and salaries. I exclude very young and very old men. As indicated below, I sometimes apply more stringent selection criteria. When feasible and appropriate, I also control for three to six educational attainment categories and eight to ten experience or age groups.

Another key objective in the empirical investigation is to measure changes in comparable aspects of the wage structure across many countries. Unfortunately, limitations on data availability plus cross-country differences in educational systems, sample design, and other factors conspire against the construction of earnings measures and detailed controls for worker characteristics that are fully consistent across countries. These difficulties largely dictate my focus on a few broad aspects of the wage structure related to overall wage inequality, earnings differentials by age and educational characteristics, earnings inequality within sex-education-age groups, and industry relative wages.

Table 1 lists the source, earnings concept, selection criteria and other key features of the data used to measure relative worker wage changes in each country. Given the objectives outlined above, an ideal data set would contain annual statistics on a timeconsistent measure of earnings cross-tabulated by sex, educational attainment, and age (or

'Earnings data for women are less readily available for several countries in the sample, another consideration that weighs in favor of a focus on men. 
experience). Furthermore. the earnings statistics would be based on a national probability sample that contains a large number of observations in each sex-education-age cell.

The data set for the United States approaches this ideal most closely, whereas the data sets for other countries present serious limitations along at least one dimension. Limitations related to short time series and infrequent observations will be evident in the figures and tables presented below. Certain less evident limitations for particular countries merit explicit caveats. For instance, the German wage measures reported below are calculated from two different household surveys. Likewise, the 1968-1982 and 1984-1988 Swedish wage figures reported below are based on two different surveys. As a separate matter, the statistics reported below for Brazil. Venezuela and Sweden are calculated from samples not restricted to full-time workers.

Another caveat relates to incomplete sample coverage in certain countries. The sampling frame for the liorean data encompasses only establishments with ten or more regular employees. As a consequence. the manufacturing sector is greatly over represented in the Korean data, whereas the agricultural sector and certain service industries are unrepresented or greatly under represented. Furthermore, because of massive industrial restructuring in Korea over the past two decades (Kim and Topel, 1992), the relative size of the covered sector increased dramatically. Differences between the covered and uncovered sectors in levels or trends of earnings inequality potentially lead to biases in the changes in overall Korean earnings inequality reported below. Provided that labor is mobile across sectors, these differences do not bias reported measures of age and education differentials. As indicated in Table 1 , some other countries also adopt sampling frames that exclude certain sectors of the work force. However, the magnitude of the uncovered sector and of changes in the relative size of the uncovered sector over the sample period is much smaller in these countries than in Korea.

As a final caveat. cross-country comparisons of levels of relative wage measures should be approached with special caution due to cross-country differences in sample design and selection criteria. These differences are apt to create less serious problems for cross-country comparisons of changes in relative wage measures. Readers can form judgments about the quality of these comparisons from the information contained in Table 1 and the notes to the figures. 


\section{Trends in Wage Inequality}

Overall Wage Inequality

Figure 1 displays the time path of overall wage inequality in eight advanced economies. Panel A reports the differential between the 90th and 10th percentiles of the log wage distribution, and Panel $\mathrm{B}$ reports the standard deviation of the log wage distribution. The data at my disposal permit me to calculate only one of these statistics for many countries. Unfortunately, I lack the information required to measure overall wage inequality in Japan.

The figure reveals that overall wage inequality rises sharply during the 1980 s in several advanced economies. The recent surge in overall wage inequality in Australia, Canada. West Germany and the United Kingdom appears comparable in magnitude to the sharp and well-documented increase in the United States. ${ }^{2}$ Following a sharp compression of the wage structure between 1068 and 1081, Swedish wage inequality rose moderately between 1984 and 1988. Drawing on a variety of data sources, Hibbs (1990) and Edin and Holmlund (1991) also find moderate increases in Swedish wage inequality after 1983. France and the Netherlands stand out among the advanced economies as showing stable levels of wage inequality during the 1980 s.

The magnitude of the rise in wage inequality experienced by many advanced economies during the 1980s is impressively large. Between 1979 and 1989 in the United States, the standard deviation of $\log$ wages rose from .64 to .75 , and the differential between the 90 th and 10 th percentiles of the wage distribution expanded by $31 \log$ points. Given the stagnant real wage growth experienced by the United States during this decade, this sharp rise in wage inequality translates into sharp real wage declines for workers in the lower deciles of the wage distribution (Juhn, Murphy and Pierce (1990), Katz and Murphy (1992), Levy and Murnane (1992), and many others). Except for the United Kingdom, the other countries represented in Figure 1 also experienced slow or negative real wage growth during the 1980s. Thus, the pattern of rising earnings inequality depicted in Figure 1 translates into real wage declines during the 1980s for large fractions of the work force in several advanced economies.

The time series plotted in Figure 1 enable me to characterize longer term movements in earnings inequality in five countries. U.S. earnings inequality began increasing in the late 1960s and accelerated in the 19S0s. Canada shows a similar pattern of rising earnings inequality during the 1970s, followed by an acceleration in the 1980s. In the United Kingdom, earnings inequality declined modestly during the early 1970s and then rose after

${ }^{2}$ Borland (1092) reports more modest increases in Australian wage inequality during the 1980 s than illustrated in Figure 1.B. 
1077 at a pace only slightly below that of the United States. In France, overall earnings inequality remains remarkably stable between 1967 and 1987 compared to other advanced economies. The Swedish pattern of increasing compression until the early 1980s followed by moderately expanding wage inequality after 1983 is closely linked to institutional developments in the Swedish labor market. Both blue-collar and white-collar Swedish labor organizations actively pursued egalitarian wage policies from the middle 1960s until the breakdown of centralized wage bargaining in 1993 (Hibbs (1990), Edin and Holmlund (1991)).

Figure 2 displays changes in overall wage inequality in four middle income economies. In contrast to the advanced economies. wage inequality declines sharply during the 1970s and 1080s in Korea. Venezuela and Colombia. In Brazil, wage inequality changes little over the sample period but rises moderately between 1982 and 1985. The 1982-1985 increase in the Brazilian standard deviation of log wages corresponds to less rapid inequality growth than all advanced economies displayed in Figure 1.B except the Netherlands. In short. a comparison of Figures 1 and 2 points to systematic differences between advanced and middle income economies in overall earnings inequality trends. The comparison encourages explanations for earnings inequality movements that highlight systematic differences between advanced and middle income countries in realized labor market disturbances over the past two decades, or systematically different responses to a common set of disturbances due to differences in levels of economic development, factor endowment proportions, or labor market institutions.

Developments in the Top and Bottom Parts of the Distribution

Some insight into the reasons for rising wage inequality can be garnered by separating changes in the bottom part of the earnings distribution from changes in the top part. Explanations for trends in earnings inequality that stress the role of minimum wage laws bear directly on developments in the bottom part of the distribution. Explanations that stress changes in high-end marginal income tax rates bear directly on the top part of the distribution. Explanations that stress the role of unions and other wage-bargaining institutions are likely to bear most heavily on the bottom and middle parts of the earnings distribution.

Figure 3 plots the evolution of the 90-50 and 50-10 log wage differentials in five countries. The figure reveals remarkable differences in the structure of wage inequality across the four advanced economies. The two North American economies show much greater wage dispersion in the bottom half of the distribution than either France or the United Kingdom. Indeed. during the 1980s the U.S. 50-10 log wage differential exceeds twice the 
corresponding French and U.K. differentials. By the 1980s, the Canadian 50-10 log wage differential also substantially exceeds the corresponding French and U.K. differentials. In contrast. these four advanced economies show much more similarity in wage differentials over the upper half of the distribution. The French $90-50$ log wage differential, for example, appears comparable in magnitude to the corresponding U.S. differential.

A simple way to summarize these dramatic cross-country differences in the structure of wage inequality is to compare the ratio of the $90-50$ to the 50-10 log wage differential. In 1986. this ratio varies from .63 in Canada (1985), .72 in the United States. 1.12 in the United Kingdom, 1.13 in Australia (Borland, Table 6), and 1.67 in France. ${ }^{3}$ To the extent that these advanced economies have broadly similar structures of labor demand and labor supply, these calculations point to cross-country differences in government labor market interventions and wage-setting institutions as powerful determinants of the structure of wage inequality

Turning to time-series changes in the $90-50$ and 50-10 log wage differentials, additional patterns emerge. The bottom and top parts of the log wage distribution exhibit substantial spreading that dates from the middle to late 1960 s in the United States and the middle to late 1970s in the United Kingdom. In Canada, wage inequality in the bottom half of the wage distribution rose as rapidly during the 1970s and 1980s as in the United States, but the top half of the Canadian wage distribution actually became more compressed between 1970 and 1980 . Alone among the four advanced economies, Canada shows no net spreading in the top half of the wage distribution between 1970 and 1985.

France shows moderate increases in the $00-50$ log wage differential after 1973. In contrast, the $50-10 \log$ wage differentials in France shrinks slowly but steadily until 1984. As Figure $3 . B$ indicates, this shrinking $50-10 \mathrm{log}$ wage differential sets France apart from the other advanced economies. This observation - and the earlier observation that the ratio of the 90.50 to 50-10 log wage differential in France far exceeds the corresponding ratio in the other advanced economies - supports the emphasis that Katz and Loveman (1991) place on the role of wage-setting institutions and minimum wage laws as determinants of the French wage structure. Katz and Loveman note that union-negotiated agreements in France directly influence the level and structure of wages for union and nonunion employees. These agreements produce industry-wide minimum wage levels that apply to all firms in

${ }^{3}$ These statistics are calculated from gross labor earnings for broadly representative samples of full-time male employees in each country; hence. it is unlikely that the large observed differences in the structure of wage inequality across countries simply reflect differences in sample coverage, earnings concept, or measurement methods. 
the industry. In addition. the French government mandates an inflation-indexed minimum wage that applies to virtually all sectors of the economy. Katz and Loveman report that the French minimum wage rose from $61 \%$ of the mean nonagricultural wage in 1979 to $69 \%$ in $198 \%$. As evidence for the view that the legal minimum represents an increasingly important determinant of the French wage structure, they also report a substantial increase in the fraction of French workers who receive the prescribed minimum wage and a very sharp increase in the unemployment rate of 15-24 year olds after the late 1970s.

Summary

In summary, Figures 1-3 carry three main messages. First, rising wage inequality during the 1980s is a common. though not universal, phenomenon among the advanced economies. Several advanced economies exhibit increases in wage inequality comparable to the increase experienced by the United States. Second. and in clear contrast, three out of four middle income countries considered here exhibit sharply declining wage inequality since the middle to late 1970 s. Finally, remarkably large differences in the structure of wage inequality across advanced economies and distinctive aspects of French and Swedish wage inequality developments point to wage-setting institutions and government labor market interventions as powerful influences on relative wages.

\section{The Evolution of Age-Earnings Differentials}

Basic Patterns

Figure 4 summarizes the evolution of cross-sectional age-earnings profiles for men in five advanced economies and two middle income economies. The plotted values represent the ratio of mean earnings for prime age men to mean earnings for younger men. Age groups differ somewhat across countries and are listed separately in each panel.

The time series depicted by asterisks control for broad changes in the educational composition of age-group employment by calculating age-group earnings means as fixedweight averages of mean earnings in three to six educational attainment categories. The weights equal average education-group shares of age-group employment or weeks worked over the available sample period. Time series depicted by squares represent ratios of raw age group means and. hence, entail no controls for changes in the education composition of age-group employment.

The most remarkable pattern in Figure 4 is the increase in earnings differentials between prime age and younger men in the advanced economies. The United States, Japan, United Kingdom and France exhibit large and persistent increases in age-earnings differentials. Age-earnings differentials apparently began rising during the late 1960 s in the United 
States and in the early to mid-1070s in France, the Linited Kingdom and Japan. Canada shows more moderate increases in age-earnings differentials that date from the late 1970s.

Table 2 summarizes the magnitude of increases in age-earnings differentials in nine advanced economies. drawing on Figure 4 and tabulations reported by Gottschalk and Joyce (1991) Every advanced econorny except Sweden exhibits a clear pattern of sharply rising age-earnings differentials. According to Table 2.B., Germany shows the sharpest rise during the 1980s, but Table 2.A. indicates that several countries experienced large cumulative increases in age-earnings differentials. In France, the age-earnings differential between prime age and younger men rose by 29-34 percentage points between 1973 and 1987. In the Linited States, the age differential rose by 22.54 percentage points between the late 1060s and 198T.

Figure $t$ also displays the evolution of age-earnings differentials for Brazil and South Korea. In Brazil. earnings differentials between prime age and younger men rise by 8.13 percentage points from 1976 to 1985 . South Korea, in contrast, shows sharp declines in age-earnings differentials between 1976 and 1982 and partial reversals thereafter.

Figure 5 displays the evolution of age-earnings differentials by education group for four countries and by broad occupational category for the United Kingdom. Plotted values depict the ratio of mean earnings for 40-49 or $45-49$ year old men to mean earnings for 25-29 year old men. Increases in age-earnings differentials are more pronounced among less educated workers in the United States, Canada, Sweden (not shown) and Japan. Age differentials among college-educated workers actually shrink after 1982 or 1983 in the United States and Japan. ${ }^{*}$ In the United Kingdom, age differentials evolve similarly for manual and nonmanual workers.

Strong differences across education groups in the evolution of age differentials occur in South Korea. Age differentials fall sharply among less educated workers between 1971 and 1983. In contrast, they rise modestly for high school-educated workers and dramatically for college-educated workers between 1971 and 1983. Splicing the figures from micro data and published sources at the 1986 overlap indicates that the mean earnings differential between prime age and younger college-educated Korean men rose by $i \tau$ percentage points from 1971 to 1938 . This upsurge in the relative wage for more experienced coilege-educated Kiorean men dwarfs the comparatively modest swings in the returns to experience among

-Based on total earnings, the age differential among college-educated men in Japan shrinks by 12 percentage points from 1082 to 1088 rather than the $i$ point drop illustrated in the nggure. The 1982-1085 rise in age differentials among less educated workers is virtually the same for contract and total earnings. 
L.S. workers that have occupied the attention of Freeman (1979), Welch (1979), Katz and Murphy (1092) and many other researchers.

Although not displayed here. I have also examined the evolution of age-earnings differentials for women in the United States. United Kingdom, France and Canada using the same measures. controls and samples as in Figures 4 and 5. Not surprisingly, levels of age differentials are smaller for women than men in all countries. Patterns of rising wage differentials are roughly comparable between men and women in France and the United States. In Canada, age differentials begin rising sooner for women than for men. and the increases are larger for well-educated women than for their male counterparts. In the United Kingdom. age differentials rise more modestly for women than for men.

Summery and Interpretation

Summarizing the main empirical finding of this section, the advanced economies show sharply increasing returns to experience. Where data are available, the increases in the returns to experience date from the late 1960s to mid 1970s, depending on country, sex, and education group. Increases are larger and more persistent for less educated men, and they occur among women as well as men.

In thinking about the implications of this evidence on age-earnings differentials, a few observations are useful. A basic point is that time-series patterns of shifts in the relative supply of less versus more experienced workers are likely to differ somewhat across the advanced economies. Likewise, time-series patterns of country-specific relative demand disturbances may also differ substantially. In light of these potentially quite different patterns of relative supply and demand shifts, the broad similarities across the advanced economies in the evolution of age differentials are remarkable. These similarities strongly favor a unified interpretation of the observed changes in age-earnings differentials.

One interpretation maintains that - due to international trade in goods and factor mobility - the wage structures of the advanced economies have been closely linked over the sample period, so that important relative labor supply and demand disturbances alter the wage structure in similar ways across the various advanced economies regardless of the precise geographic origin of disturbances. While this interpretation appears attractive in light of the evidence on age-earnings differentials, other evidence is less congenial to a strong form of this view. In particular. other aspects of changes in the wage structure exhibit less uniformity among the advanced economies than changes in age-earnings differentials. In addition. empirical studies consistently find that U.S. relative supply movements induce large U.S. relative wage responses. These observations do not deny that trade among the advanced economies create important cross-national linkages of relative wage structures, 
but they indicate that the geography of relative demand and supply disturbances matters greatly for the geography of relative wage responses.

A second interpretation of the observed changes in age-earnings differentials accords with the view that barriers to factor mobility and goods trade among the advanced economies remain substantial, so that country-specific disturbances largely involve countryspecific consequences for the wage structure. This interpretation maintains that some relative labor demand or supply disturbance common to the advanced economies is at play, and that this worldwide disturbance is large enough to alter the wage structure in qualitatively similar ways across the advanced economies - despite cross-country differences in relative supply shifts, relative demand shifts, and wage-setting institutions.

One natural hypothesis regarding age-earnings differentials stresses the similar timing of postwar baby booms across many advanced countries. Given imperfect substitutability in production between younger and older workers, the entrance of baby boom cohorts into the work force will tend to depress the relative wages of younger workers. While relative supply shifts probably play an important role in the recent evolution of age-earnings differentials in many advanced economies, it seems unlikely that a simple supply-shift story can explain the continued increase in age-earnings differentials during the 1980s. In the United States, for example, the relative supply of young-to-old worker equivalents had stabilized by 1980 (Katz and Murphy, Figure V).

Other potential explanations for a common pattern of persistently rising age-earnings differentials stress alternative sources of relative demand shifts against younger workers. One candidate for this common source of relative demand shifts is some form of technological change that favors more experienced workers (Mincer, 1991). Another candidate for a common relative demand shift is increased trade in goods (and factors) between the advanced economies and the less developed economies. An explanation along these lines would maintain that skills accumulated through work experience in the advanced economies are in relatively short supply in the less developed economies. A third, not necessarily independent, explanation stresses the role of a common pattern of industrial restructuring across the advanced economies. A shift in employment demand towards sectors that intensively utilize the bundle of skills accumulated through work experience, or a shift toward sectors that exhibit relatively steep experience profiles, will tend to depress the relative wages of younger workers. 


\section{Changes in Education Differentials}

Basic Patterns

Figure 6 displays the evolution of education differentials in four advanced economies and four middle income economies. Plotted values represent the ratio of mean earnings for more educated workers to mean earnings for less educated workers. These ratios control for changes over time in the age or experience composition of education groups. Figure $\bar{i}$ shows separate plots of education differentials for less experienced and more experienced men in three countries. Table 3 draws on Figure 6. tabulations of raw education group means in Gottschalk and Joyce, and other sources to summarize the pattern and magnitude of changes in education differentials during the 1970s and 1980s.

The time series plotted in Figure 6 show a clear pattern of declining education differentials during the 1970 s in the United States. Japan. the United Kingdom and Canada. In Japan. the downward trend in education differentials evidently dates back to 1954 or earlier, whereas declining U.S. education differentials during the 1970 s represent a break from developments in the 1950s and 1960s (Goldin and Margo (1992), Katz and Murphy (1992)).

The top panel of Table 3 summarizes changes in college/high school wage ratios in the United States and comparable ratios in five other advanced economies. The summary reveals moderate to very large declines in the returns to education during the 1970 s across all six advanced economies shown in the table. Freeman (1981) observed a similar pattern of declining returns to education during the 1970s among advanced economies. Figure 7 indicates that declining education differentials during the 1970 s held for both experienced and inexperienced men in Canada and the United States. In Japan, educational differentials rose modestly during the second half of the 1970 s and continued to rise thereafter for the least experienced workers.

Comparing the top and middle panels of Table 3 reveals a striking contrast between falling education differentials during the 1970s and rising differentials in the 1980s. Over the latter decade. education differentials were flat in Japan, and they rose moderately to rapidly in the United States. United Kingdom, Canada, Sweden, Australia, and West Germany. The Netherlands is a glaring exception to this pattern. While the basic pattern of falling then rising education differentials is common to all of the advanced countries except the Netherlands, the U.S. experience is extreme. U.S. education differentials rise more rapidly during the 1980s than any other advanced economy, and the United States is the only advanced economy to show a net increase in the college wage premium over the two decades as a whole. 
Turning to the middle income economies, Table 3 show sharp declines in education differentials during the 1080s, declines that extend back into earlier years where data are available. To place the magnitude of these changes in perspective, note that the declining education differentials during the 1080s in Colombia, Venezuela and South Korea appear at least as large in magnitude as the increasing education differentials in the United States.

Summary and Interpretation

We can summarize the chief empirical regularities conveyed by Table 3 and the corresponding figures in three statements. First, among the advanced economies education differentials fell sharply during the 1970s. Second, among the advanced economies the path of education differentials subsequently became flat or rising during the 1980s. And third, education differentials fell sharply among middle income income economies during the 1980s.

Several plausible interpretations of the cross-country patterns of change in education differentials merit careful investigation. One interpretation of developments during the 1980 s stresses the role of factor price equalization effects resulting from increased trade between the advanced economies - where highly educated labor is relatively abundant - and the less advanced economies - where highly educated labor is relatively scarce. A difficulty with a simple explanation along these lines is that the world economy grew increasingly integrated during the 1970s as well, and we have seen that education differentials in the advanced economies shrank substantially during this decade. ${ }^{3}$

A complementary trade-based explanation for movements in education differentials stresses movements in the trade deficit rather than the growth in balanced trade. At least in the United States, export sectors rely intensively on highly skilled labor inputs, whereas import sectors rely intensively on less skilled labor (Kuhn and Wooton, 1991; Borjas, Freeman and Katz, 1991). Thus, holding the volume of international trade fixed, an increase in the trade deficit shifts relative labor demand toward more highly skilled workers. Wurphy and Welch (1002) present evidence that points toward swings in the trade deficit as an important source of relative labor demand disturbances over the past two decades in the United States. However, explanations that stress the role of trade deficits seem incapable of explaining the broad similarities in the movements of education differentials among the advanced economies over the past two decades.

\footnotetext{
${ }^{3}$ In the United States, for example, imports plus exports rose from $12 \%$ to $24 \%$ of GNP during the 1070s. whereas their share of GNP shows essentially no net change between 1980 and 1088. See Figure 2 in Abowd and Freeman (1091).
} 
Another plausible interpretation of the patterns in Table 3 is that the relative supply of highly educated workers grew more rapidly during the 1970s than the 1980 s in the advanced economies, and that relative supply growth has been especially rapid in the middle income economies. Taken as a whole, previous studies already offer a strong case for the importance of relative supply movements. Numerous anlayses of movements in L:S. education differentials attribute a major explanatory role to relative supply shifts - Bound and Johnson (1989) and Katz and Murphy (1992) are two recent examples. Analyses of Brazil by Lam and Levison (1992) and South Korea by Kim and Topel (1992) and Kwark and Rhee (1992) also find that changes in education differentials are closely associated with relative supply shifts. Studies by Katz and Revenga (1989) and Freeman and Needels (1931) find that comparatively slow growth in the relative supply of collegeeducated workers in the United States helps to explain the more rapid growth of college wage premiums during the 1980s in the United States than in Japan or Canada. Thus, it seems likely that relative supply shifts will play an important role in any full accounting for the empirical regularities documented in Table 3.

Mincer (1991). Kiatz and Murphy (1992) and others argue that the U.S. time-series evidence on education differentials and relative supply movements supports an interpretation that postulates strong secular growth in the relative demand for more educated workers. This interpretation for the joint time-series behavior of relative wages and relative supplies in the United States has a natural counterpart in the cross-country context. In particular, one would like to know whether cross-country differences in the evolution of education differentials and the corresponding relative supply movements support an explanation that postulates steady and comparable increases in the relative demand for more educated workers across all countries, or at least across countries with similar levels of economic development.

A third interpretation of Table 3 stresses time variation in the rate of skill-biased technical change as an explanation for movements in education differentials. Mincer (1991), Krueger (1991), Davis and Haltiwanger (1991), and Bound and Johnson (1991) offer various pieces of evidence that point towards skill-biased technical change as a factor responsible for recent increases in U.S. skill differentials. Becker (1975, chapter VI), Mincer (1991), and Katz and Murphy (1992) appeal to skill-biased technical change as a force that has helped maintain high rates of return to schooling in the face of large secular increases in the relative supply of more educated workers. A convincing story based on skill-biased technical change would need to be augmented with some compelling explanation for crosscountry differences in the time path of education differentials. Differences in relative supply 
growth are one possibility. Differences in industrial structure across countries or differences in the spread of certain technologies (e.g., computers) are other possibilities.

While they have their attractions. explanations for movements in education differentials that stress skill-biased technical change entail some discomforting aspects. These explanations tend to rely heavily on indirect evidence and unobservables. There seems, as yet, no clear evidence on which sectors are the wellsprings of skill-biased technical change. Furthermore. it seems difficult to reconcile the notion of steady increases in the relative demand for more educated workers due to steady skill-biased technical change with the stagnant growth of productivity and real wages across many advanced economies during the last ten to twenty years.

A fourth interpretation of the results in Table 3 argues that cross-country differences in patterns of industrial restructuring explain cross-country differences in the time path of education differentials. This interpretation is not necessarily independent of trade-based or technology-based interpretations. At a broad level, a finding that shifts in the industrial composition of employment toward skill-intensive sectors in advanced economies and away from shill-intensive sectors in middle income economies would support this interpretation. Hincer (1001) and Katz and Murphy (1092) present evidence that shifts in the industrial and occupational composition of employment account for part of the increase in the relative demand for more educated workers in the United States. Bound and Johnson (1989) offer a more negative assessment. Gottschalk and Joyce (1991) present evidence that several advanced economies exhibit a shift in the composition of employment toward relatively skill-intensive one-digit industry groups.

In sum, international trade, relative supply shifts, technical change, and industrial restructuring each offer some potential to explain movements in education differentials. In principle. a pooled cross-country time-series investigation can confront alternative explanations with the data in a much more powerful way than studies that focus on a single country. The data amassed and summarized here represent a step in that direction.

\section{Changes in Wage Inequality among Observationally Similar Workers}

\section{Basic Patterns}

Figures 8 and 9 depict time paths of within-group wage inequality measures in eight advanced and three middle income economies. Due to data limitations. the definition of a group varies across countries. For the United States, Canada and Korea the plotted values represent average levels of inequality within experience-by-education groups. The data for the Lnited Kingdom represent average levels within age-by-occupation groups. For Brazil 
and Venezuela the plotted values reflect regression controls for education and experience or age. The data for France. West Germany, Sweden, Australia and the Netherlands control for education or age but not both. Except for Venezuela, all plotted values represent fixedweight averages of within-group inequality measures in each country. Thus, Figures 8 and 9 control for shifts over time in the education and/or age composition of employment.

Among the advanced economies, the predominant pattern during the 1080 s is a movement toward sharply higher wage inequality among observationally similar workers. ${ }^{6}$ France, which exibits moderately declining inequality within narrow age groups since $197 \pi$, is the only clear exception to this pattern. A more detailed examination of the French case shows secular declines in the 90-75, $75-50,50-25$ and 25-10 log wage differentials within one-year age groups. These declines date back to at least 1975. Thus, the distinctive path of within-group wage inequality in France does not seem directly linked to increases in the French minimum wage.

Figure 9 displays the movements in within-group wage inequality for three middle income countries. Korea and Venezuela exhibit sharply declining wage inequality among workers with similar years of schooling and experience. Indeed, the declines in within-group inequality in these two middle income countries appear considerably larger in magnitude than the increases in within-group inequality among U.S. workers. The other middle income country in the sample, Brazil, exhibits a modest decline in within-group inequality between 1976 and 1982 but an increase between 1982 and 1985.

\section{Summary and Interpretation}

In summary. Figures 8 and 9 convey three main messages. First, the rising wage inequality among observationally similar workers in the United States is a widespread phenemon among advanced economies during the 1980s. Second, like the United States, Brazil and the Netherlands exhibit quite different time paths for within-group inequality as compared to education differentials. These different time paths suggest that education differentials and within-group inequality are driven by distinct forces (Juhn, Murphy and Pierce, 1091). Third, the limited sample of countries considered here points to systematic differences between advanced and middle income economies in the recent evolution of within-group wage inequality.

${ }^{6}$ The displayed data for Sweden suggest a modest decline in wage inequality within education groups between 1081 and 1988, but data tabulated by Gottschalk and Joyce from a different source show sharply rising wage inequality within broad age groups. This discrepancy appears to reflect differences between the two data sets rather than differences in the control variables. 
The widespread nature of rising within-group earnings inequality among the advanced economies sheds light on the appropriate interpretation of this rise in any one country. For example, a potentially attractive explanation for rising within-group wage inequality in the United States is an increasing dispersion of unobservable worker quality attributes due to increasingly unequal educational quality. Juhn, Murphy and Pierce (1991) point out that similarities across age groups in the timing and magnitude of the rise in within-group inequality in the United States argue against the schooling quality interpretation. In the absence of any other plausible supply-side explanation for rising within-group inequality, they infer that the phenomenon reflects changes in the structure of labor demand that favor unobserved dimensions of worker skill. Figure 3 buttresses this inference, since it is unlikely that several advanced economies simultaneously experienced an increase in the dispersion of unobservable worker quality atcributes. Thus, Figure 8 directs our attention toward common demand-side explanations for rising within-group inequality in each country.

Alternatively, rising within-group wage inequality might reflect a relaxation of wagesetting institutions that formerly acted to compress wage differences among workers. The Swedish pattern of declining within-group inequality until the early 1980 s, followed by expanding within-group inequality after the 1983 breakdown of centralized wage bargaining, is broadly consistent with this type of interpretation. However, Figure 8 indicates that a compelling explanation along these lines for the United States must confront the similar increases in within-group inequality across several of the advanced economies.

\section{Industry Relative Wage Movements in the Manufacturing Sector}

I now turn my attention from relative worker wages to relative industry wages. At the same time. I shift the focus of the investigation from changes in the wage structure within individual countries to summary statistics that indicate whether relative industry wage structures become more or less uniform across countries. To motivate and structure the empirical analysis below, I begin by developing a set of related hypotheses.

\section{Relative Factor Price Equalization: A Partial Convergence Hypothesis}

The Heckscher-Ohlin-Vanek theorem of international trade states that countries export the services of abundant factors and import the services of scarce factors (Vanek (1068). Leamer (1034)). In other words. international trade in goods augments the effective supply of a country's scarce factors and increases the derived demand for its abundant factors. To the extent that international trade flows adhere to the pattern predicted by this theorem. factor prices are likely to become more equalized across countries. Indeed, the Heckscher-Ohlin-Samuelson factor price equalization theorem states conditions under 
which free trade in goods yields identical factor prices in all countries despite the immobility of factors between countries (Samuelson, 1048).

While a proof of the factor price equalization theorem requires restrictive assumptions, it is worth stressing that factor price equalization effects arise in a variety of theoretical models. Helpman and Krugman (1086), for example, develop theories of international trade based on (i) cross-country differences in factor endowment proportions, (ii) external increasing returns to scale at the industry level, (iii) imperfect competition with contestable markets, and (iv) differentiated products with monopolistic competition. For each of these theories, they display equilibria in which free trade in goods leads to the full equalization of factor prices across countries. Factor price equalization effects also arise when international trade is partly or entirely driven by cross-country differerences in available production technologies (Don Davis. 1901). Thus. a reasonable conclusion to draw from the theoretical literature is that international trade in goods imparts a tendency toward factor price equalization under a wide range of circumstances.

As it turns out, the factor price equalization theorem is grossly at variance with the data. For example, Leamer (1984, page 11) reports that in a sample of thirty-two countries, hourly wage rates in agriculture vary from $\$ .046$ in India to $\$ 2.04$ in Denmark. As Leamer puts it, "Part of these differences might be explained by skill differences, but agricultural wages seem unlikely to include a reward for skills that is sufficiently variable to account for the data .... This observation encourages a search for assumptions that do not necessarily imply factor price equalization."

Notwithstanding the empirical falsification of the factor price equalization theorem, the idea that free trade in goods imparts some tendency toward the equalization of factor returns resonates strongly for economists and many other observers. Political calls for protectionist trade policy often seem motivated by a clear recognition that less educated, and much lower paid, workers in other countries present a threat to attractive employment opportunities for less educated U.S. workers. Empirical research into the sources of rising wage inequality in the United States indicates that differences between domestic factor endowment proportions and the net factor content of imports and exports played an important role in changes in the wage structure during the 19S0s. Borjas, Freeman and Katz (1991) find that the growth in the U.S. trade deficit between 1980 and 1985 "produced a large increase in the implicit supply of less educated workers, particularly high school dropouts. but had only a slight effect on the implicit supply of college graduates." They estimate that the effect of an expanding U.S. trade deficit on the structure of labor demand accounts for $15-25 \%$ of the rise in the college/high school earnings differential between 1980 
and 1985.' Recent studies by Freeman and Katz (1991), Murphy and Welch (1992), and Revenga (1092) also point to significant effects of international trade on the structure of labor demand and relative wages in the United States.

The preceding discussion makes essentially three points: First, international trade in goods imparts a tendency towards factor price equalization in a variety of theoretical models. Second, the theoretical proposition that international trade fully equalizes factor returns across countries fails spectacularly. Third, empirical research indicates that international trade has important effects on the wage structure, and at least some of this evidence points toward the empirical relevance of factor price equalization effects. This state of affairs encourages one to formulate hypotheses that preserve the central logic of the factor price equalization theorem while also holding some prospect of surviving a confrontation with the data on cross-country movements in relative wages.

In essential first step coward the formulation of empirically useful hypotheses is to dispense with the assumption of identical technologies across countries. Without allowing for cross-country differences in technology, broadly interpreted, we will be unable to accomodate Leamer's observation. In any case, total factor productivity varies enormously across countries. and the traditional factor proportions theory is not designed to explain these differences. Consequently, it is inappropriate to reject the theory simply because cross-country differences in factor prices reflect cross-country differences in total factor productivity.

If we introduce Hicks-neutral differences in technology across countries, while preserving the other assumptions of Heckscher-Ohlin theory, the standard line of proof yields the prediction that iree trade in goods equalizes relative factor prices across countries. This prediction, too, fails in a direct confrontation with the data - though not so spectacularly - and explanations for its failure are not hard to find.

An obvious and important reason for cross-country differences in relative factor prices is the presence of transport barriers that impede international trade in goods. Coupled with cross-country differences in relative factor supplies, costly trade rationalizes crosscountry differences in relative wages. Even free international trade in goods would not induce full equalization of relative wages across countries. The reasons are many: Nonlabor factor supplies vary across countries, and these nonlabor factors differentially influence the

\footnotetext{
Although Borjas, Freeman and Katz find that U.S. exports rely more intensively on skilled labor inputs than U.S. imports (see, also, Kuhn and Wooton (1991)), their analysis indicates that balanced trade growth in the United States has had only modest effects on the structure of labor demand and relative wages.
} 
efficiency of different labor inputs. Similarly, technology differences, kcross countries need not take a Hicks-neutral form. In addition. unobserved quality differences between "equally skilled" workers in different countries lead to measured differences in relative wages, even in the absence of true differences.

These considerations indicate that empirically useful hypotheses regarding factor price equalization effects relate changes in the extent of barriers to international trade to changes in the pattern of relative wages across countries. A central hypothesis of this form maintains that widespread reductions in international trade barriers lead to the partial convergence of relative wage structures across countries. Specifically, relative wages fall for workers who have skills that are scarce in their home country relative to worldwide skill supply proportions. Conversely, relative wages rise for workers who have skills that are in relatively abundant supply in their home country. Since, according to the theory, the initial cross-country pattern of relative wages reflects the cross-country pattern of relative skill supplies. greater international integration of national economies induces greater uniformity across countries in relative wage structures.

One testable version of this partial convergence hypothesis focuses on cross-country differences in education differentials. According to the hypothesis, reductions in the barriers to international goods trade among the world's national economies compress the cross-country distribution of education differentials. Furthermore, the hypothesis predicts that easier international trade in goods causes the largest declines (increases) in education differentials in countries with the smallest (largest) relative supply of highly educated workers. Since highly educated workers are typically in relatively short supply in poor countries and relatively abundant supply in wealthy countries, this second prediction can also be stated in terms of relative per capita income rather than relative supplies of highly educated workers.

The evidence amassed in Table 3 for the 1980s is broadly consistent with this prediction of partial convergence in education differentials. During the 1980s, education differentials are relatively high and falling in the middle income economies, and they are relatively low and rising in the advanced economies. But the table also indicates that education differentials fell during the 1970 s in the advanced economies, and this pattern fails to conform to the unconditional partial convergence hypothesis.

A preferred approach - but more demanding in its data requirements - to testing the partial convergence hypothesis conditions on country-specific relative supply movements and, possibly, other sources of country-specific relative demand disturbances. Relatively rapid growth in the supply of educated workers in poorer countries can induce cross-country 
convergence of education differentials, even when international trade barriers remain unchanged. Thus. country-specific supply side factors may entirely account for the partial convergence of education differentials found in Table 3 for the 1980s. While partial convergence in education differentials remains an interesting finding, an explanation based on country-specific relative supply movements carries very different implications than an explanation based on factor price equalization effects.

It is also preferable to drop the maintained assumption that barriers to international trade have generally fallen in recent decades when testing the partial convergence hypothesis. One can attempt to directly measure the time variation in each country's openness to international trade. Ideally, one would measure the net factor content of imports and exports for each country-year observation, but this is an extremely demanding data requirement. In practice. most researchers resort to simple proxies for international openness like the trade deficit or the sum of exports and imports as a share of GNP.

These partial convergence hypotheses can be recast in terms of the industry wage structure rather than the structure of relative wages among workers. According to the factor proportions theory, reduced barriers to international trade lead to greater similarities across countries in the factor intensities used to produce traded goods. Under completely free trade. the theory maintains that any traded good produced in two different countries is produced with identical factor intensities. Thus, greater international openness induces greater cross-country uniformity in factor intensities and in the structure of relative wages among workers. These remarks indicate that reductions in barriers to international trade in goods lead to greater cross-country uniformity in the structure of relative industry wages.

\section{- Test for Cross-Country Convergence of Industry Wage Structures}

According to the factor proportions theory sketched above, free trade in goods induces uniformity across countries in the relative industry wage structure for traded goods. Motivated by this implication of the theory, I investigate whether the within-country relative industry wage structure became more uniform across countries between 1975 and 1989 .

To formulate a precise hypothesis, some notation is useful. Let $j$ index worker type, $i$ index industry, and $c$ index country. Mean hourly wages for industry $i$ in country $c$ can be written as a simple weighted average

$$
W_{i c}=Z_{c} w_{i c}=Z_{c} \sum_{j} \theta_{i c}^{j} w_{i c}^{j},
$$

where $\theta^{\prime}$ denotes the share of industry $i$ hours accounted for by type-j workers. $Z_{c}$ captures different currency units for different countries and cross-country differences in average real 
hourly wages due to differences in the overall level of productivity. Hence, the $w_{i c}$ represent relative industry wages within country $c$, and the $w_{i c}^{\text {r }}$ represent relative wages for different worker types. For the empirical analysis carried out below, it is unnecessary to specify the numeraire for either of these relative wage concepts.

Competitive markets and free inter-industry mobility of workers within countries imply that, for every $j, w_{i c}^{j}$ is equalized across all $i$ within each country. Further, under the conditions envisioned by the Heckscher-Ohlin-Samuelson factor price equalization theorem (but allowing for Hicks-neutral productivity differences across countries), the following two conditions hold: First, relative worker wages are equalized across countries - i.e, $w_{c}^{j}$ is equalized across all $c$ for every $j$. Second, factor intensities in the production of traded goods are equalized across countries - i.e., $\theta_{i c}^{j}$ is equalized across all $c$ for every combination of $i$ and $j$. Taken together, these two conditions imply the equalization of industry relative wages across countries. Thus, taking logs in (1) and adding an error term, we can write

$$
\log \left(W_{i c}\right)=F_{c}+A_{i}+u_{i c},
$$

where $F$ denotes country fixed effects, $A$ denotes industry fixed effects, and the $u_{i c}$ reflect deviations from the benchmark of perfectly equalized relative industry wages.

According to the theory, nonzero values of the residual term arise when barriers to international trade, coupled with cross-country differences in relative factor supplies. prevent the full equalization of relative worker wages across countries. In the limiting cases of either free trade or identical factor endowment proportions across countries, the theory predicts a perfect fit for the regression equation (2). Aside from the elements stressed by the theory, measurement error, cross-country differences in product mix within industries, cross-country differences in technology, noncompetitive aspects of wage determination, and other forces generate cross-country differences in the relative industry wage structure.

Recognizing that many forces imply deviations from the free-trade benchmark implied by the theory, I investigate whether these deviations diminished in recent years, as would be suggested by the theory under a general pattern of falling trade barriers or greater cross-country similarity in factor endowment proportions. In other words, I investigate the hypothesis that the standard error of the residual in cross-sectional regressions of the form (2) has declined in recent years.

The empirical investigation relies on unpublished data from the Bureau of Labor Statistics at the U.S. Department of Labor. ${ }^{8}$ The BLS data set reports annual observations 'The data set, "Hourly Compensation Costs in Manufacturing Industries," is compiled by the Office of Productivity and Technology at the BLS. The data set used here is dated April 1901. 
of mean gross hourly compensation costs for production workers by country-industry unit. Industry definitions correspond to two- and three-digit industries in the U.S. Standard Industrial Classification system. ${ }^{9} I$ exclude observations on industry-country units that BLS flags as a less satisfactory match to the industry definitions for other countries. The resulting data set contains annual observations from 1975 to 1989 on $6-41$ industries in 14 advanced economies and 5 middle income economies. Observations on a larger set of 16 advanced economies and 8 middle income economies are available from 1977 to $1985 .{ }^{10}$

Using various samples drawn from these data, I run weighted and unweighted regressions of the form (2) for each year. Weights equal country shares of world international trade (exports plus imports) during the year. ${ }^{11}$ The worldwide average structure of industry relative wages implied by the trade-weighted regressions reflects a weight for each country that is proportional to its contribution to world trade, whereas the implied average in the unweighted regressions gives equal weight to all countries. Partly because the data overwhelmingly reject the hypothesis of no systematic difference in the relative industry wage structure between advanced and middle income economies, I report results for samples that include all available countries and samples restricted to advanced or middle income economies.

Figure 10 summarizes the results of the investigation based on the trade-weighted regressions. The unweighted regressions yield broadly similar results. ${ }^{12}$ Each plotted value

${ }^{9}$ To maximize the number of cross-country comparisons, I do not restrict the data set to non-overlapping industries within each country. For example, the U.S. data include observations on SIC 24. SIC 25. and a combined industry that ecompasses SIC 24 and 25. For some other countries, wages are available only for the combined industry.

${ }^{10}$ Excepe for Singapore, I designated as "advanced" any country with GDP per capita in excess of $\$ 9.000$ (1985 dollars) in Table II of Summers and Heston (1991). The advanced economies are Austria, Belgium, Canada. Denmark, Finland, France, Germany, Hong liong, Israel, Italy, Japan, the Netherlands. Sweden, Switzerland, the United Kingdom. and the United States. The middle income economies are Brazil, Greece, Ireland, South liorea. Portugal. Singapore, Spain. and Taiwan. I exclude observations on India because of implausibly large year-to-year sivings in relative industry wages.

"Import and export data are drawn from the International Monetary Fund's International Einancial Statistics.

${ }^{12}$ The number of industry-country observations per year varies from about 170 in the 3 -country sample of middle income countries to about 550 in the 24 -country sample. Observation counts vary slightly through time within samples due to (minor) changes in industry coverage for certain countries. 
in Figure 10 represents the standard error of the residual in the indicated year and for the indicated sample. For example. the plot for the 19-country sample indicates that the average deviation of industry relative wages about the worldwide trade-weighted mean relative wage structure equals 17.8 percent in 1975.

The results illustrated in Figure 10 strongly reject the hypothesis of increasing uniformity across countries in the relative industry wage structure. According to the 19-country sample, the standard error of the residual rose from 17.8 percent in 1975 to 21.9 percent in 1988, an increase of $23 \%$. Most of this increase occurred between 1976 and 1982 . The broader sample of 24 countries and the narrower sample of 16 advanced countries show similar patterns of divergence. Thus, contrary to the prediction of a factor proportions theory under the maintained hypothesis of reduced barriers to trade and greater similarity in factor endowment proportions, industry relative wage structures diverged over the past two decades.

\section{International Trade and Partzal Convergence: Further Tests}

As a test of the theory, the results depicted in Figure 10 suffer from three difficulties of interpretation. First, the maintained hypothesis of reduced barriers to international trade (or increased similarity in factor endowments) may be false. ${ }^{13}$ Second, even if the maintained hypothesis is true, some unobserved force unrelated to international openness may be driving the divergence of relative industry wages. Third, Figure 10 provides no information about the magnitude of any association between a country's trade openness and the deviation of its industry relative wage structure from the worldwide average structure. These difficulties can be overcome, and a sharper test of the theory can be constructed. by measuring the time variation in each country's openness to international trade.

Fully satisfactory measures of openness to international trade are difficult to devise and construct, especially for a large sample of countries. Here, I use changes in trade as a fraction of GDP to proxy for changes in a country's openness to international trade. I then investigate whether countries that experience an increase in international openness also experience a partial convergence of industry relative wages to the worldwide average structure of industry relative wages.

To carry out the investigation, I first measure the average deviation of each country's relative industry wages about the worldwide average relative industry wage structure. This

${ }^{13}$ It seems likely, however, that the maintained hypothesis of reduced barriers to international trade is true for this sample. Only $j$ of 24 countries experienced declines in exports plus imports as a fraction of GDP from 1975 to 1989. Two countries experienced essentially no change, and 17 countries experienced an increase in trade as a fraction of GDP. 
step amounts to simply computing the standard deviation of the residuals for each countryyear unit in the first-stage cross-sectional regressions of the form (2). These standard deviations by country-year serve as the dependent variable in a second-stage panel regression on trade shares and other variables. To isolate the time-series variation in the dependent variable, all panel regressions include country fixed effects. To isolate the within-country time-series variation, some specifications also include year effects. Specifications with year effects control for any unobserved factors, common across countries, that might be driving the divergence of industry relative wages in Figure 10.

Table 4 summarizes the panel regressions. Three results stand out. First, controlling for year effects, increases in international trade are associated with a statistically significant convergence of industry relative wages towards the regression-implied norm. The importance of controlling for year effects can be seen by comparing the first and third rows for Sample $C$, which contains observations on 16 high income countries over the 1975-1988 period. After controlling for year effects, the estimated effect of trade is also negative and statistically significant in Samples $A$ and B, which contain both high and middle income economies. Thus, the theoretical prediction that increased openness induces greater cross-country uniformity in industry relative wage structures finds support in the data. This result indicates that the cross-country divergence depicted in Figure 10 reflects some unobserved factor that more than offsets the convergence-inducing effects of greater international trade.

The magnitude of the trade-induced convergence effect is modest. Based on the Sample-C estimates for specifications that include year effects, a ten point increase in trade as a percentage of GDP reduces the standard deviation of the first-stage regression residuals by $.40-.57$ percentage points. This estimated effect amounts to roughly $2-3 \%$ of the average standard error of the residuals in the first-stage regressions and roughly $10-15 \%$ of the increase in the regression standard error over the sample period.

Second. the estimates indicate that the convergence-inducing effects of international trade are limited to the high income economies. This point can be seen in the last two rows of Table 4, which consider panel regressions on the eight middle income economies. The Sample-D regression tests whether trade induces a convergence to the average industry wage structure among middle income economies only. The Sample-AD regression tests whether trade induces convergence to the average industry wage structure among all $\mathbf{2 4}$ countries. Since the first-stage regressions are trade-weighted, the implied average relative industry wage structure in the Sample-AD regression is predominantly determined by the wage structure among the high income economies. These regression results for the middle 
income economies provide no evidence of any convergence-inducing effects of international trade.

Third. the Sample-C regressions reveal large and statistically significant differences between the effects of imports and exports on relative industry wages. Import growth induces a large and statistically significant convergence toward the average structure of relative industry wages, whereas export growth induces a smaller and statistically significant divergence. The factor proportions theory does not provide an explanation for this asymmetry.

To gauge the quantitative significance of the asymmetry, it is useful to consider the experience of a particular country. From 1975 to 1988 , U.S. imports rose from $\overline{7} .63$ to 11.40 percent of GDP. while exports rose from 8.48 to 8.89 percent. Based on the coefficient estimates in the fourth row of the Sample-C regressions, the U.S. time path of exports and imports reduced the deviation of U.S. relative wages about the average by .009 . This effect is roughly four times as large as the reduction implied by the corresponding Sample$C$ regression that imposes symmetry. Between 1975 and 1988, the actual U.S. standard deviation of residuals increased by .005 based on the trade-weighted regressions and by .007 based on the unweighted regressions. Hence, over the sample period relative industry wages in the United States diverged moderately from the average structure among high income countries. The estimates indicate that this divergence would have been two or three times larger had the United States experienced no change in exports and imports as a fraction of GDP.

\section{Concluding Remarks}

The preceding investigation documents several prominent cross-country patterns of change in key aspects of the relative wage structure. These empirical regularities indicate that many key developments in the U.S. wage structure over the last two decades reflect forces that operated on a global scale. In this respect, the analysis encourages a focus on explanations for wage developments in the linited States and other individual countries that stress factors common to many countries.

At the same time, the duration and extent of increases in overall wage inequality, the comparatively sharp increase in education differentials, and other aspects of the U.S. experience during the past two decades place it at the upper extreme among the advanced economies. In addition, the paper identifies highly distinctive aspects of wage structure developments in several other countries, including Canada. France and Sweden. In this respect, the analysis encourages a focus on research designed to explain the large outliers 
- that is. the aspects of country-specific wage developments that deviate sharply from the predominant cross-country pattern.

It seems likely that our understanding of wage structure developments will progress most rapidly if research simultaneously proceeds along several fronts. Detailed studies of individual countries are essential for identifying exogenous policy interventions and for drawing out the role of complex institutional developments that defy easy summary. At the other extreme. broader brush multi-country analyses of panel data sets offer potentially much greater leverage for evaluating competing interpretations of wage structure developments and for estimating the quantitative impacts of particular types of disturbances. As this paper illustrates, multi-country studies also serve to identify and conveniently summarize some central features of wage structure developments. 


\section{References}

Abowd, John .I. and Richard B. Freeman (1001) "Introduction and Summary," in Immigration. Trade, and the Labor Market. Chicago: University of Chicago Press. Becker. Gary S. (19i5) Human Capital. Chicago: The University of Chicago Press. Blackburn. McKinley and David Bloom (1990) "Changes in the Structure of Fam. ily Income Inequality in the U.S. and Other Industrialized Nations During the 1980s." Lniversity of South Carolina.

Borjas. George J., Richard B. Freeman, and Lawrence F. Katz (1991) "On the Labor Market Effects of Immigration and Trade," NBER working paper no. 3761.

Borland. Jeff (1992) "Wage Inequality in Australia," Presented at the NBER Universities Conference on the Labor Market in International Perspective. Cambridge, Massachusetts.

Bound, John and George Johnson (1989) "Changes in the Structure of Wages During the 1980s: An Evaluation of Alternative Explanations," NBER working paper no. 2983.

Cutler, David M. and Lawrence F. Katz (1992) "Rising Inequality? Changes in the Distribution of Income and Consumption in the 1980s," NBER working paper number 3964.

Davis. Don (1091) "Intraindustry Trade: A Heckscher-Ohlin-Ricardo Approach," Columbia University

Davis, Steven J. and John Haltiwanger (1091) "Wage Dispersion between and within C.S. Manufacturing Plants." Brookings Papers on Economic Activity: Microeconomics. $115 \cdot 180$.

Edin. Per-Anders and Bertil Holmlund (1991) "The Swedish Wage Structure: The Rise and Fall of Solidaristic Wage Policy," Uppsala University, Sweden.

Freeman, Richard B. (1979) "The Effect of Demographic Factors on Age-Earnings Profiles." Journal of Human Resources. 14, no. 3.

Freeman. Richard B. (1981) "The Changing Economic Value of Higher Education in Developed Economies: A Report to the OECD," NBER working paper no. 820.

Freeman, Richard B. (1991) "How Much Has De-Unionization Contributed to the Rise in Male Earnings Inequality?" NBER working paper number 3826.

Freeman. Richard B. and Lawrence F. Katz (1091) "Industrial Wage and Employment Determination in an Open Economy," in John Abowd and Richard Freeman, eds.. Immigration. Trade, and the Labor Market, Chicago: University of Chicago Press. 
Freeman Richard B. and Karen Needels (1091) "Skill Differentials in Canada in an Era of Rising Labor . Market Inequality." NBER working paper no. 3827.

Goldin. Claudia and Robert A. Margo (1092) "The Great Compression: The Wage Structure in the Lnited States at Mid-Century," Quarterly Journal of Economics, 107 1-34.

Gottschalk. Peter and Mary Joyce (1991) "Changes in Earnings Inequality - An International Perspective." working paper number 66, The Luxembourg Income Study.

Gottschalk, Peter and Robert Moffitt (1992) "Trends in Earnings Mobility in the United States, 1968-1988," presented at the American Economics Association meetings in New Orleans.

Helpman. Elhanan and Paul R. Krugman (1986) : Narket Structure and Foreign Trade. Cambridge, Massachusetts: The MIT Press.

Hibbs. Douglas A.. Jr. (1990) "Wage Compression under Solidarity Bargaining in Sweden" in Inga Persson-Tanimura. ed., Generating Equality in the Welfare State: The Swedish Experience. Norwegian University Press.

Juhn. Chinhui, Kevin M. Murphy, and Brooks Pierce (1991) "Wage Inequality and the Rise in the Returns to Skill." forthcoming in the Journal of Political Economy. Katz, Lawrence F. and Gary Loveman (1990) "An International Comparison of Changes in the Structure of Wages: France, The United Kingdom, and the United States," Harvard University.

Katz. Lawrence F. and Kevin M. Murphy (1992) "Changes in Relative Wages, 1963 1937: Supply and Demand Factors." Quarterly Journal of Economics, 107, 35-78.

Latz, Lawrence F. and Ana L. Revenga (1989) "Changes in the Structure of Wages: The United States versus Japan," Journal of the Japanese and International Economies, 3. $522-553$.

Kim. Dae Il and Robert Topel (1092) "Labor Markets and Economic Growth: Lessons from Liorea's Industrialization. 1070-1990," Presented at the NBER Universities Conference on Labor Markets in an International Perspective, Cambridge, Massachusetts.

Krueger, Alan (1991) "How Computers Have Changed the Wage Structure: Evidence from Microdata, 1084-89," NBER working paper number 3858.

liuhn. Peter and Ian Wooton (1091) "Immigration, International Trade, and the Wages of Native Workers," in John .W. Abowd and Richard B. Freeman, eds., Immıgratıon. Trade. and the Labor Market. Chicago: The University of Chicago Press.

Kivark. Noh-Sun and Changyong Rhee (1992) "Educational Wage Differentials in lorea." University of Rochester. 
Lam. David and Deborah Levison (1992) "Declining Inequality in Schooling in Brazil and its Effects on Inequality in Earnings," Journal of Development Economics, 97, 199-225.

Leamer. Edward E. (1384) Sources of International Comparative Advantage. Cambridge, Massachusetts: The MIIT Press.

Levy, Frank and Richard J. Murnane (1991) "Earnings Levels and Earnings Inequality: A Review of Recent Trends and Proposed Explanations," forthcoming in the Journal of Economic Literature.

Londono, Juan Luis (1990) Income Distribution During Structural Transformation: Colombia 1998.1988, unpublished Ph.D. dissertation, Harvard University.

Miller, Paul W. (1984) "Education and the Distribution of Earned Income," in Richard Blandy and Owen Covick, eds., Understanding Labour Markets, Allen and Unwin Inc., IVinchester, Massachusetts.

Nincer, Jacob (1991) "Human Capital. Technology, and the Wage Structure: What Do Time Series Show?" NBER working paper no. 3581.

Murphy, Kevin M. and Finis Welch (1992) "The Structure of Wages" Quarterly Journal of Economics. 107, 285-326.

Psacharopoulos. George and Asad Alam (1091) "Earnings and Education in Venezuela:】 An Update from the 1987 Household Survey," Economics of Education Review. 10, no. 1, 29-36.

Psacharopoulos, George and Francis Steier (1988) "Education and the Labor Market in Venezuela, 1975-1084," Economics of Education Review, 7, no. 3, 321-332.

Revenga, Ana L. (1992) "Exporting Jobs: The Impact of Import Competition on Employment and Wages in U.S. Manufacturing," Quarierly Journal of Economics, 107, no. 1, 255-284.

Samuelson, Paul A. (1948) "International Trade and the Equalization of Factor Prices," Economic Journal, 59, no. 2, 181-197.

Summers, Robert and Alan Heston (1991) "The Penn World Table (Mark 5): An Expanded Set of International Comparisons, 1950-1988," Quarterly Journal of Economics, 106, 327.368.

Vanek, Jaroslav (1968) "The Factor Proportions Theory: The N-Factor Case." Kyklos, 21, no. 4, 749-756.

Welch, Finis (1979) "Effects of Cohort Size on Earnings: the Baby Boom Babies' Financial Bust." Journal of Political Economy, 37, part 2. 
Table 1. Wage Data Sets

\section{United States}

Data Source - Annual Demographic Files, March Current Population Survey (CPS).

Earnings Concept - Weekly wage (annual earnings divided by weeks worked) in the year prior to the survey.

Selection Criteria - Wage and salary earners, 18-64 years old, working at least 40 weeks and earning more than one-half the minimum wage on a full-time basis.

Remark - Adjustments for top coding, bracketed values for weeks worked, and the 1976 change in CPS imputation procedures as in Katz and Murphy (1992).

\section{Japan}

Data Source - Basic Survey on Wage Structure (BS), published volumes. (Historical Statistics of Japan is the proximate source for 1954-1965 and some later years.)

Earnings Concept - Monthly wage and salary payments; total earnings equal contract earnings plus overtime payments plus one-twelfth of bonus payments in previous year.

Selection Criteria - Regular workers, 18-64 years old, at non-governmental establishments with at least 5-10 regular workers (size cutoff varies over time). Excludes agriculture, forestry and fisheries, domestic service, and employees of foreign governments and international agencies.

Remarks - (i) $70,000-100,000$ establishment surveyed in a typical year. (ii) Changes (apparently minor) in the sampling frame over time.

United Kingdom

Dato Sources - Published volumes of the New Earnings Survey (NES), except for education differentials. Education differentials are estimated by Schmitt (1991) from the General Household Survey (GHS).

Earnings Concept - Gross weekly earnings.

Selection Criteria - NES: full-time employees, 21-64 years old, whose pay was not affected by absence during the survey period. GHS: full-time employees.

Remark - (i) NES: a one percent sample of employees covered by pay-as-you-earn income tax schemes. (ii) GHS: a CPS-style survey of ten-to-fifteen thousand households per year.

France

Dala Source - Tabulations from the Declarations Annuelles de Salaires (DAS).

Earnings Concept - Gross annual earnings, adjusted for differences among persons in annual hours worked.

Selection Criteria - Full time, full year workers in private and semi-public firms.

Remarks - (i) A four percent sample of workers in the covered sector. (ii) The DAS consists of two panels with a fixed composition through time. One panel runs from 1962 to 1982 with no observations for 1981, and a second panel runs from 1984 to 1987.

Canada

Data Sources - Individual record files of the Household Census in 1971, 1981 and 1986: family record files of the Survey of Consumer Finances (SCF) in 1976, 1980 and 1988.

Earnings Concept - Weekly wages (annual earnings divided by weeks worked) in the year prior to the survey.

Selection Criteria - Census: 18-64 year old men who worked at least 40 weeks, had annual earnings greater then 1,200 and weekly earnings less than 5,000 1981 Canadian dollars, and had self-employment income less than $25 \%$ of wage and salary income. SCF: 
Table 2.A. Rising Age-Earnings Differentials in the Advanced Economies

\begin{tabular}{|c|c|c|c|c|}
\hline Country & $\begin{array}{l}\text { Age Group } \\
\text { Ratio }\end{array}$ & Trough Year & $\begin{array}{l}\text { Increase in } \\
\text { Age-Group Mean } \\
\text { Trough \& } 1987\end{array}$ & $\begin{array}{l}\text { the Ratio of } \\
\text { Earnings Between } \\
1975 \text { \& } 1987\end{array}$ \\
\hline United States & $45-49 / 20-24$ & 1967 & .57 & .34 \\
\hline United States & $45-49 / 25-29$ & 1969 & .22 & .10 \\
\hline Japan ${ }^{\alpha}$ & $40-49 / 20-24$ & 1974 & .17 & .14 \\
\hline Japana & $40-49 / 25-29$ & 1976 & .15 & .13 \\
\hline United Kingdom & $40-49 / 21-24$ & $1975-77$ & .15 & .15 \\
\hline United Kingdom & $40-49 / 25-29$ & 1974 & .10 & .10 \\
\hline France & $45 / 27$ & 1973 & .34 & \\
\hline France & $45 / 25$ & 1973 & .29 & .25 \\
\hline Canada $b$ & $45-49 / 20-24$ & 1979 & .14 &. .02 \\
\hline Canadab & $45-49 / 25-29$ & 1979 & .07 & -.01 \\
\hline Swedenc & $21-25 / 0-5$ & & & -.12 \\
\hline Sweden ${ }^{c}$ & $21-25 / 6-10$ & 1981 & .07 & .06 \\
\hline
\end{tabular}

Earnings concept, data source, selection criteria and calculation of age-group means as in Table 1 and Figure 4. The Swedish figures are fixed-weight averages over five education groups.

Additional Notes:

(a) Based on total earnings.

(b) Based on the Survey of Consumer Finances.

(c) Ratios of experience group means using 1974 instead of 1975 and 1986 instead of 1987.

Table 2.B. Rising Age-Earnings Differentials in the Advanced Economies Gottschalk-Joyce Tabulations of LIS Data

\begin{tabular}{|c|c|c|c|c|c|c|}
\hline Country & $\begin{array}{l}\text { Age Group } \\
\text { Ratio }\end{array}$ & $\begin{array}{l}\text { Initial } \\
\text { Year }\end{array}$ & $\begin{array}{l}\text { Ratio } \\
\text { Value }\end{array}$ & $\begin{array}{l}\text { Second } \\
\text { Year }\end{array}$ & $\begin{array}{l}\text { Ratio } \\
\text { Value }\end{array}$ & $\begin{array}{l}\text { Five-Year } \\
\text { Change }\end{array}$ \\
\hline United States & $40-55 / 25-30$ & 1979 & 1.28 & 1986 & 1.46 & .13 \\
\hline Canada & $40-55 / 25-30$ & 1981 & 1.16 & 1987 & 1.33 & .14 \\
\hline West Germany & $40-55 / 25-30$ & 1981 & 1.14 & 1984 & 1.39 & .42 \\
\hline Australia & $40-55 / 25-30$ & 1981 & 1.28 & 1985 & 1.20 & .09 \\
\hline Sweden & $40-55 / 25-30$ & 1981 & 1.20 & 1987 & 1.22 & .01 \\
\hline France & $40-55 / 25-30$ & 1979 & 1.25 & 1984 & 1.40 & .14 \\
\hline United Kingdom & $n 40-55 / 25-30$ & 1979 & 1.08 & 1986 & 1.17 & .06 \\
\hline Netherlands & $40-55 / 25-30$ & 1983 & 1.30 & 1987 & 1.40 & .12 \\
\hline
\end{tabular}

Notes:

(a) Tabulations of annual earnings based on the Luxembourg Income Study, as reported by Gottschalk and Joyce (1991), Table III

(b) Selection criteria: full-time male household heads, excluding the top five percent of the earnings distribution in each age group.

(c) The Five-Year Change equals the difference between the second year and the initial year expressed on a five-year basis. 
Table 3. Changes in Education Differentials During the 1970s and 1980s

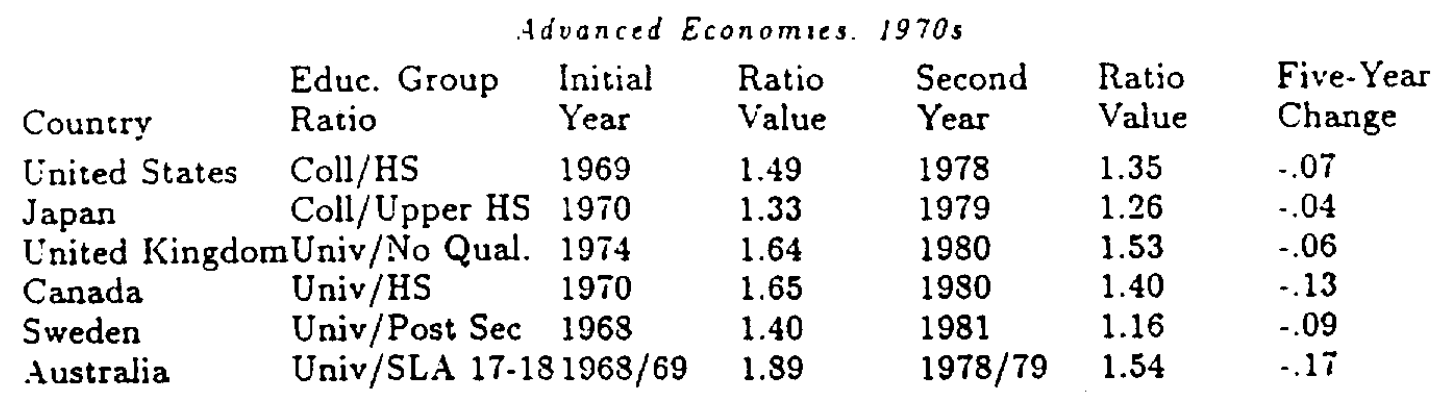

\begin{tabular}{|c|c|c|c|c|c|c|}
\hline \multicolumn{7}{|c|}{ Advanced Economies. $1980 \mathrm{~s}$} \\
\hline Country & $\begin{array}{l}\text { Educ. Group } \\
\text { Ratio }\end{array}$ & $\begin{array}{l}\text { Initial } \\
\text { Year }\end{array}$ & $\begin{array}{l}\text { Ratio } \\
\text { Value }\end{array}$ & $\begin{array}{l}\text { Second } \\
\text { Year }\end{array}$ & $\begin{array}{l}\text { Ratio } \\
\text { Value }\end{array}$ & $\begin{array}{l}\text { Five-Year } \\
\text { Change }\end{array}$ \\
\hline $\begin{array}{l}\text { United States } \\
\text { Japan } \\
\text { United Kingdom } \\
\text { Canada } \\
\text { Sweden } \\
\text { Australia } \\
\text { Netherlands } \\
\text { West Germany }\end{array}$ & $\begin{array}{l}\text { Coll/HS } \\
\text { Coll/Upper HS } \\
\text { nUniv/No Qual. } \\
\text { Univ/HS } \\
\text { Univ/Post Sec } \\
\text { Univ/Trade } \\
\text { Univ/Secondary } \\
(14-18) /(11-13)\end{array}$ & $\begin{array}{l}1979 \\
1079 \\
1980 \\
1980 \\
1081 \\
1982 \\
1083 \\
1081\end{array}$ & $\begin{array}{l}1.37 \\
1.26 \\
1.53 \\
1.40 \\
1.16 \\
\\
1.43 \\
1.36\end{array}$ & $\begin{array}{l}1987 \\
1987 \\
1988 \\
1985 \\
1986 \\
1990 \\
1987 \\
1984\end{array}$ & $\begin{array}{l}1.52 \\
1.26 \\
1.65 \\
1.43 \\
1.19\end{array}$ & $\begin{array}{l}.11 \\
0 \\
.08 \\
.05 \\
.03 \\
.03 \\
. .25 \\
.10\end{array}$ \\
\hline \multicolumn{7}{|c|}{ Middle Income Economies, $1980 \mathrm{~s}$} \\
\hline Country & $\begin{array}{l}\text { Educ. Group } \\
\text { Ratio }\end{array}$ & $\begin{array}{l}\text { Initial } \\
\text { Year }\end{array}$ & $\begin{array}{l}\text { Ratio } \\
\text { Value }\end{array}$ & $\begin{array}{l}\text { Second } \\
\text { Year }\end{array}$ & $\begin{array}{l}\text { Ratio } \\
\text { Value }\end{array}$ & $\begin{array}{l}\text { Five-Year } \\
\text { Change }\end{array}$ \\
\hline $\begin{array}{l}\text { South Korea } \\
\text { Brazil } \\
\text { Venezuela } \\
\text { Colombia }\end{array}$ & $\begin{array}{l}\text { Coll/HS } \\
(\mathrm{S}+4) / \mathrm{S} \\
(\mathrm{S}+4) / \mathrm{S} \\
(\mathrm{S}+4) / \mathrm{S}\end{array}$ & $\begin{array}{l}1979 \\
1982 \\
1984 \\
1979\end{array}$ & $\begin{array}{l}1.86 \\
1.75 \\
1.54 \\
1.71\end{array}$ & $\begin{array}{l}1988 \\
1985 \\
1987 \\
1988\end{array}$ & $\begin{array}{l}1.65 \\
1.73 \\
1.46 \\
1.47\end{array}$ & $\begin{array}{l}-.11 \\
-.03 \\
-.13 \\
-.15\end{array}$ \\
\hline
\end{tabular}

Notes:

Ratios are constructed as indicated in the notes to Figure 6, unless noted otherwise below:

(a) Sweden: Ratios of raw education group means from the LNU and HUS.

(b) Australia: Figures for the 1970s are ratios of mean earnings for 35-44 year-old men with a university degree to mean earnings for 35-44 year-old men who left school at ages 17-18, as computed from Table 2.4 of Miller (1984). The 1980s entry represents the change in the mean log wage for men with a university degree minus the change in the mean log wage for "trade qualified" men, as computed from Table 3 in Borland (1992).

(c) The entries for West Germany and the Netherlands are ratios of raw education group means from Table III in Gottschalk and Joyce (1991).

(d) Japanese figures are based on total earnings. 
full-time. non-military household heads. 18-64 years old, who worked at least 40 weeks, had weekly earnings less than 50001981 Canadian dollars, and had labor earnings as the major source of income.

Sweden

Data Source - Tabulations supplied by Per-Anders Edin from the Level of Living Survey (LNU) for 1968, 1974 and 1981; and the Household Market and Nonmarket Activities Survey (HUS) for 1984, 1986 and 1988.

Earnings Concept - Hourly earnings in the main occupation in the week preceding the survey week.

Selection Criteria - Workers, 18-64 years old, with positive earnings in the week preceding the survey week.

Remarks - (i) Small samples, containing about 3,000 workers per year in the LNU and 1300-1600 workers per year in the HUS.

West Germany, the Netherlands, and Australia

Data Source - Tabulations based on the Luxembourg Income Study, as reported by Gottschalk and Joyce (1991) in Tables III and IV.

Earnengs Concept - Annual gross wages and salaries.

Selection Criteria - Men, 25-55 years old, who are full time workers and family heads. The top $5 \%$ of the earnings distribution is excluded.

Remark - (i) German tabulations for the two available years are based on different surveys. (ii) The education differentials for Australia are from Miller (1984) and Borland (1992) as indicated below in the notes to Table 3.

Brazil

Date Source - Tabulations supplied by David Lam from the Pesquisa Nacional por Amostra de Domicilios (PNAD), a large nationally representative household survey.

Earnings Cancept - Earnings in the month prior to the survey.

Selection Criteris - Men, 22-60 years old, with positive earnings.

\section{South Korea}

Data Source - Occupational Wage Survey (OWS), published sources, plus micro data for 1971.1983 and 1986.

Earnings Concept - Monthly earnings; micro data tabulations include one-twelfth of bonus payments in previous year; published tabulations include bonus payments through 1980.

Selection Criteria - Workers, 16-64 years old, at establishments with at least ten regular employees. Excludes agricultural and governmental workers. Tabulations from micro data are restricted to full-time workers and exclude the top percentile of wage observations.

Remarks - The fraction of workers in the covered sector increased sharply during the 1970s and 1980s.

\section{Venezuala}

Data Source - Summary statistics and cross-sectional earnings regressions based on the National Household Survey, as reported by Psacharopoulos and Steier (1988, Tables 5 and 6, column 3, and Table 7) and Psacharopoulos and Alam (1991, Table 6, column 1).

Earnings Concept - Weekly (1975 and 1984) and monthly earnings (1987).

Selection Criteria - Men with positive labor earnings.

\section{Colombia}

Data Source - Computations based on urban household surveys and other sources, as reported by Londono (1991). I use the last two columns of Table 23 in Londono's statistical 
appendix to calculate education differentials. I use the asalaria entries in column 13 of Tables $27-30$ to calculate the standard deviation of log wages. 
Table 4. International Trade and Relative Industry Wages

First-Stage Cross-Sectional Regressions:

$$
\log \left(W_{i c, t}\right)=F_{c, t}+A_{i, t}+u_{i c, t}
$$

Dependent Variable in Second-Stage Panel Regressions:

$$
\left(\frac{\sum_{i=1}^{l} \hat{u}_{i c, t}^{2}}{I-1}\right)^{1 / 2} \equiv \sigma_{c, t}
$$

\begin{tabular}{|c|c|c|c|c|c|c|}
\hline $\begin{array}{l}\text { Sample } \\
\text { (\# Obs.) }\end{array}$ & $\begin{array}{l}\text { Weighted } \\
\text { lst-Stage } \\
\text { Reg. }\end{array}$ & $\begin{array}{l}\text { Country } \\
\text { Effects }\end{array}$ & $\begin{array}{l}\text { Year } \\
\text { Effects }\end{array}$ & $\begin{array}{l}\text { Coefficient } \\
\text { Exports/ } \\
\text { GDP }\end{array}$ & $\begin{array}{l}\text { Estimate (St. } \\
\text { Imports/ } \\
\text { GDP }\end{array}$ & $\begin{array}{l}\text { Err.) on } \\
\text { Trade/ } \\
\text { GDP }\end{array}$ \\
\hline $\begin{array}{l}A(198) \\
A(198)\end{array}$ & $\begin{array}{l}\text { YES } \\
\text { YES }\end{array}$ & $\begin{array}{l}\text { YES } \\
\text { YES }\end{array}$ & $\begin{array}{l}\text { NO } \\
\text { YES }\end{array}$ & & & $\begin{array}{l}-.010(.009) \\
-.030(.009)\end{array}$ \\
\hline $\begin{array}{l}\text { B (255) } \\
\text { B (255) } \\
\text { B (255) } \\
\text { B }(255)\end{array}$ & $\begin{array}{l}\text { YES } \\
\text { YES } \\
\text { YES } \\
\text { YES }\end{array}$ & $\begin{array}{l}\text { YES } \\
\text { YES } \\
\text { YES } \\
\text { YES }\end{array}$ & $\begin{array}{l}\text { NO } \\
\text { NO } \\
\text { YES } \\
\text { YES }\end{array}$ & $\begin{array}{l}-.010(.020) \\
-.048(.021)\end{array}$ & $\begin{array}{l}-.011(.023) \\
-.003(.023)\end{array}$ & $\begin{array}{l}-.010(.008) \\
-.027(.009)\end{array}$ \\
\hline $\begin{array}{l}C(210) \\
C(210) \\
C(210) \\
C(210) \\
C(210) \\
C(210) \\
C(210) \\
C(210)\end{array}$ & $\begin{array}{l}\text { NO } \\
\text { NO } \\
\text { NO } \\
\text { NO } \\
\text { YES } \\
\text { YES } \\
\text { YES } \\
\text { YES }\end{array}$ & $\begin{array}{l}\text { YES } \\
\text { YES } \\
\text { YES } \\
\text { YES } \\
\text { YES } \\
\text { YES } \\
\text { YES } \\
\text { YES }\end{array}$ & $\begin{array}{l}\text { NO } \\
\text { NO } \\
\text { YES } \\
\text { YES } \\
\text { NO } \\
\text { NO } \\
\text { YES } \\
\text { YES }\end{array}$ & $\begin{array}{l}.099(.025) \\
.046(.021) \\
.106(.025) \\
.050(.020)\end{array}$ & $\begin{array}{l}-.157(.037) \\
-.226(.031) \\
-.119(.036) \\
-.187(.030)\end{array}$ & $\begin{array}{l}-.000(.013) \\
-.057(.013)\end{array}$ \\
\hline $\begin{array}{l}D(63) \\
\operatorname{tD}(63)\end{array}$ & $\begin{array}{l}\text { YES } \\
\text { YES }\end{array}$ & $\begin{array}{l}\text { YES } \\
\text { YES }\end{array}$ & $\begin{array}{l}\text { YES } \\
\text { YES }\end{array}$ & & & $\begin{array}{l}.024(.017) \\
.022(.020)\end{array}$ \\
\hline
\end{tabular}

Results for Second-Stage Regressions

Notes:

(a) In the weighted first-stage regressions, each country's weight equals its share of world trade during the year.

(b) Samples for the first-stage regressions are as follows - Sample A: 16 high and 8 middle income countries, 1977-1985; Sample B: 15 high and 4 middle income countries, 1975 1989; Sample C: 16 high income countries, 1975-1988; Sample D: 8 middle income countries, 1977-1985. Due to missing GDP data for Taiwan and Hong Kong, some second-stage regressions involve one or two fewer countries than the corresponding first-stage regressions.

(c) "AD" indicates that the 24-country sample was used for the first-stage regression, but the second-stage regression was restricted to the sample of middle income countries.

(d) The reported number of observations is for the second-stage regression. 


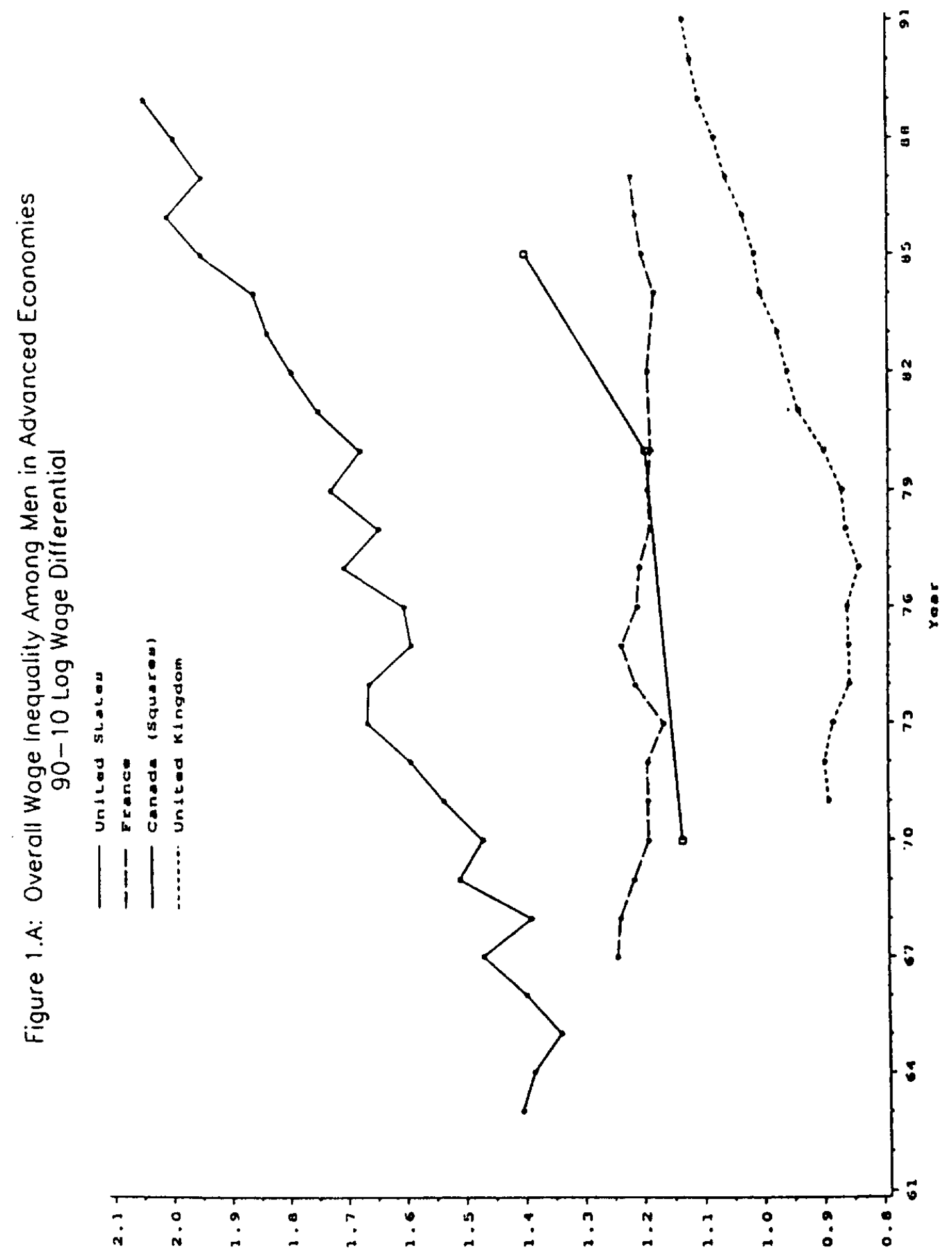




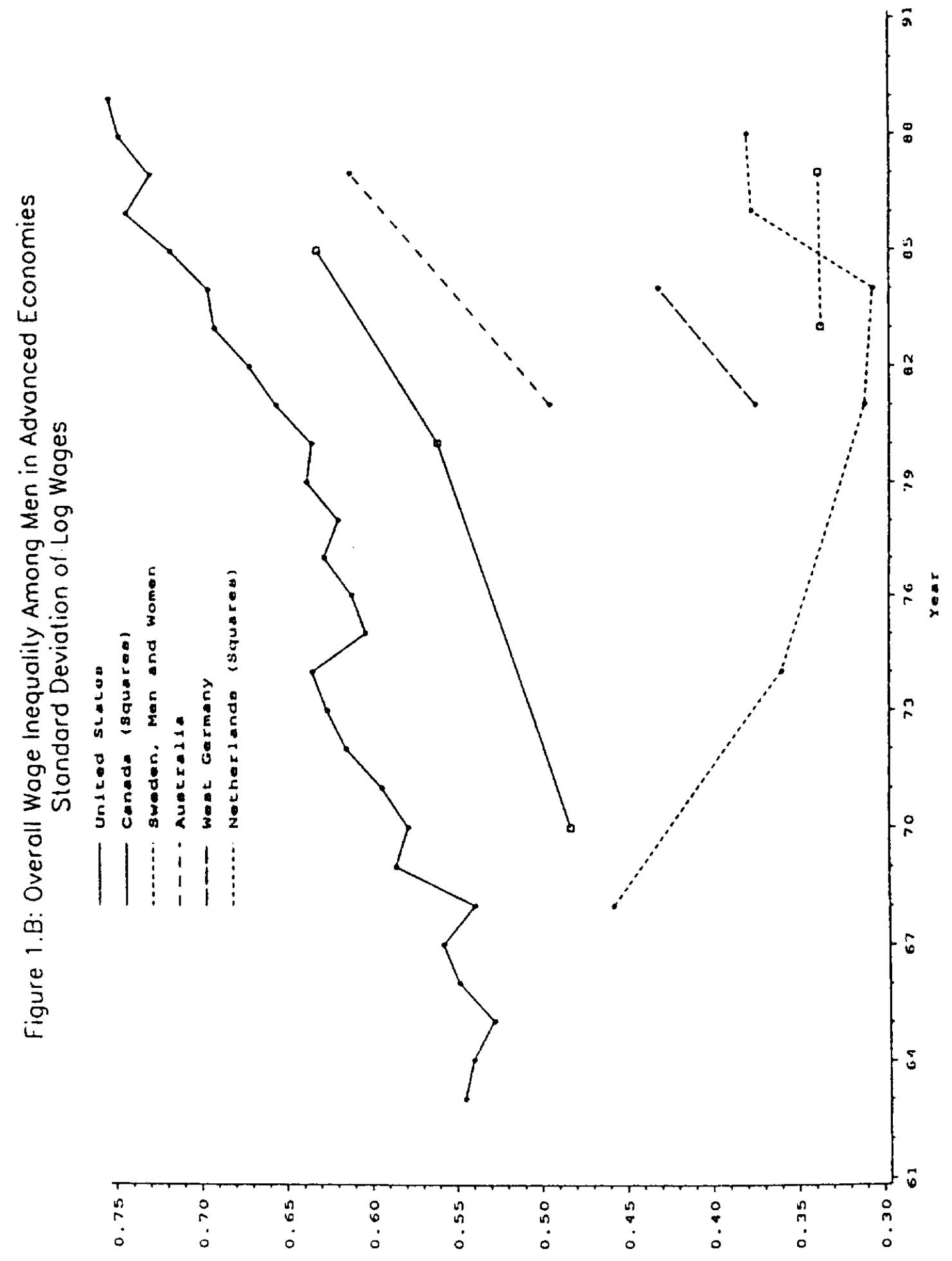




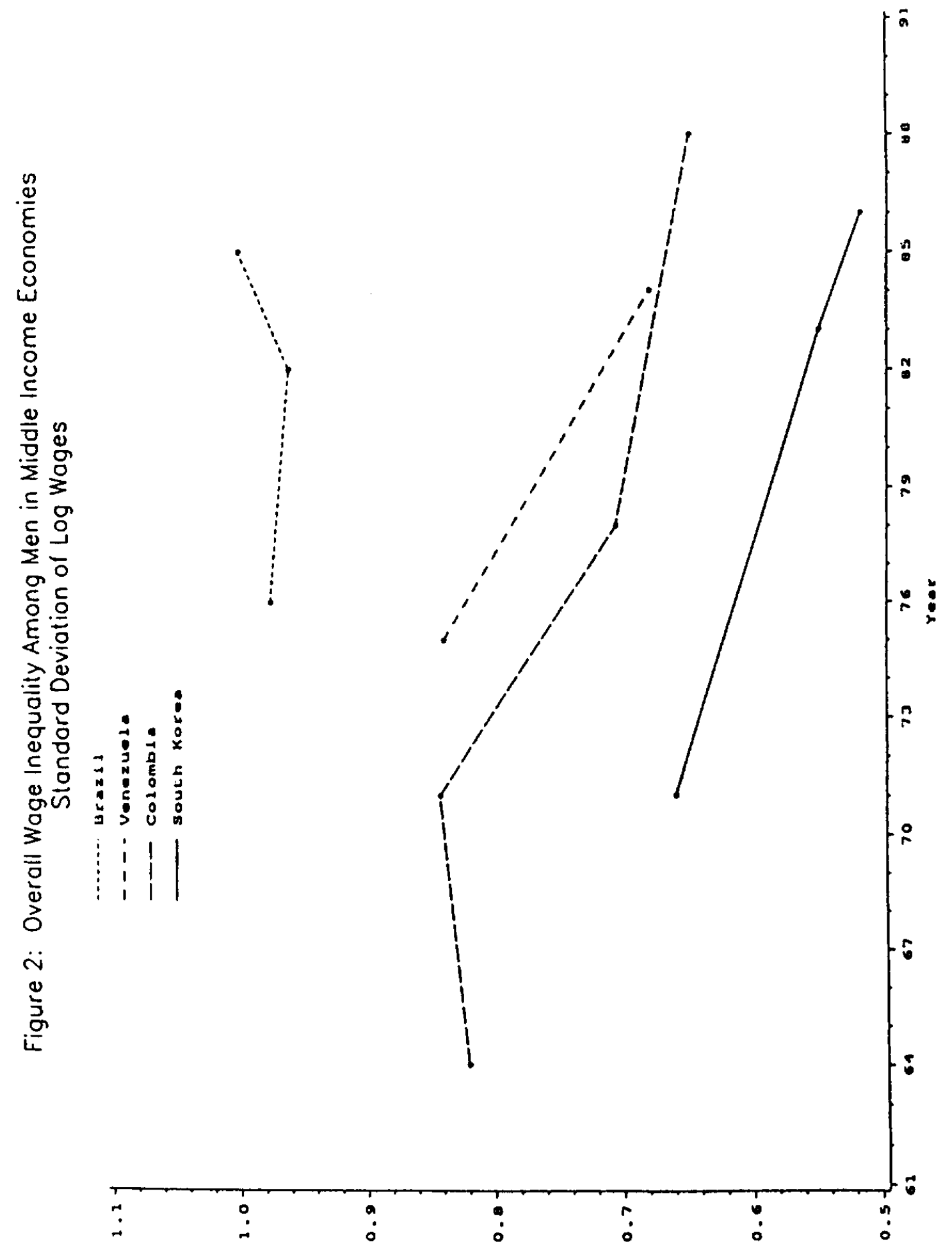




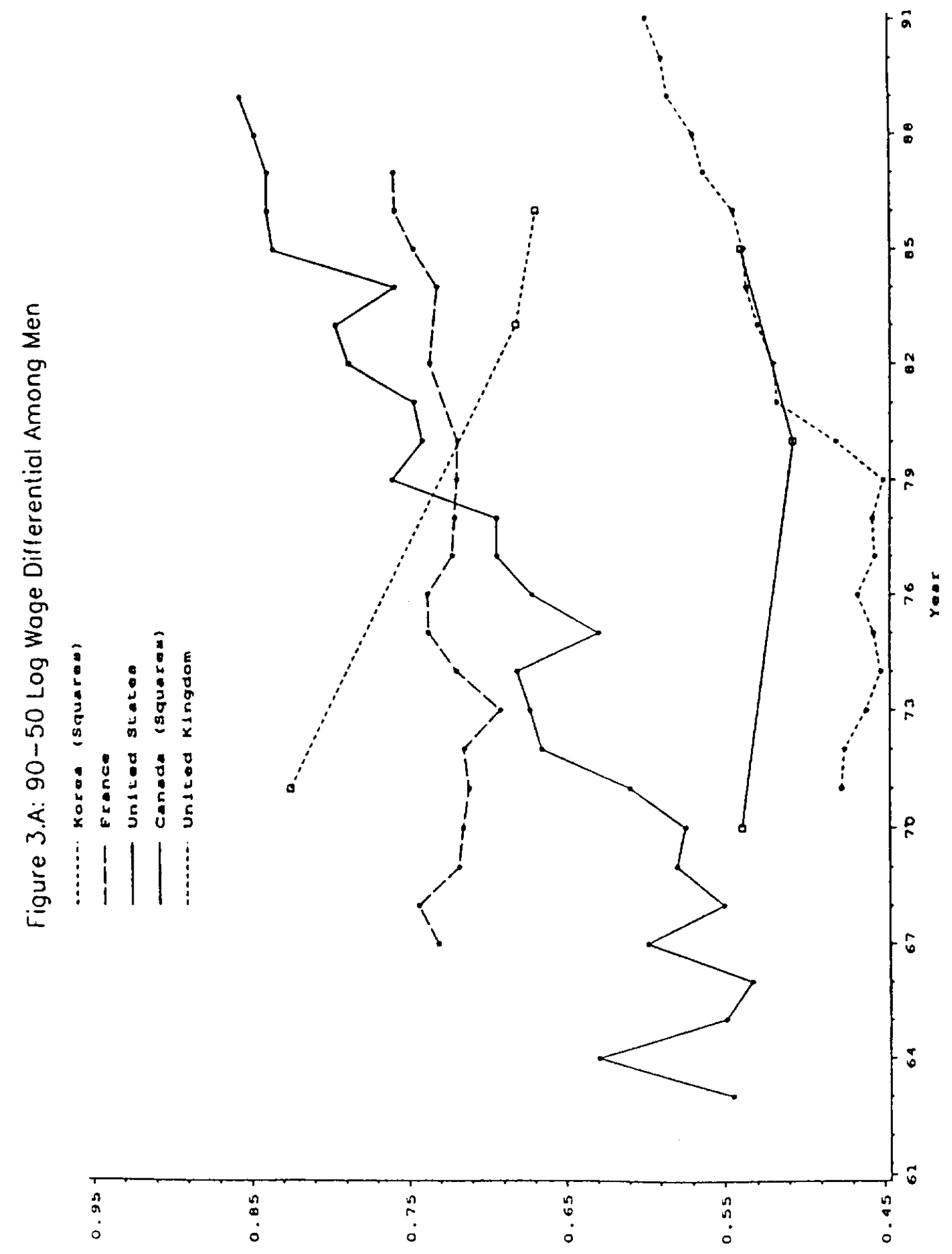




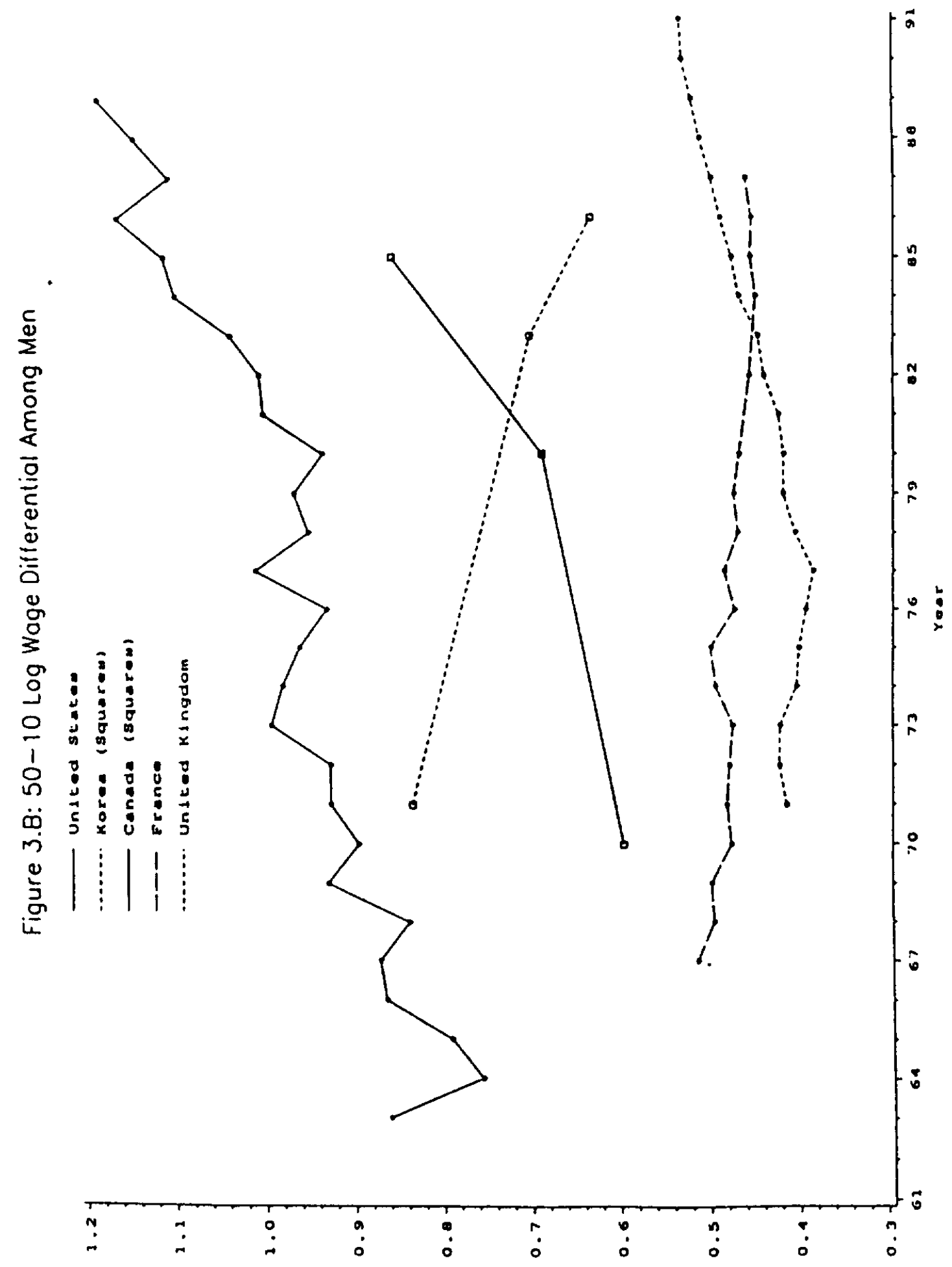




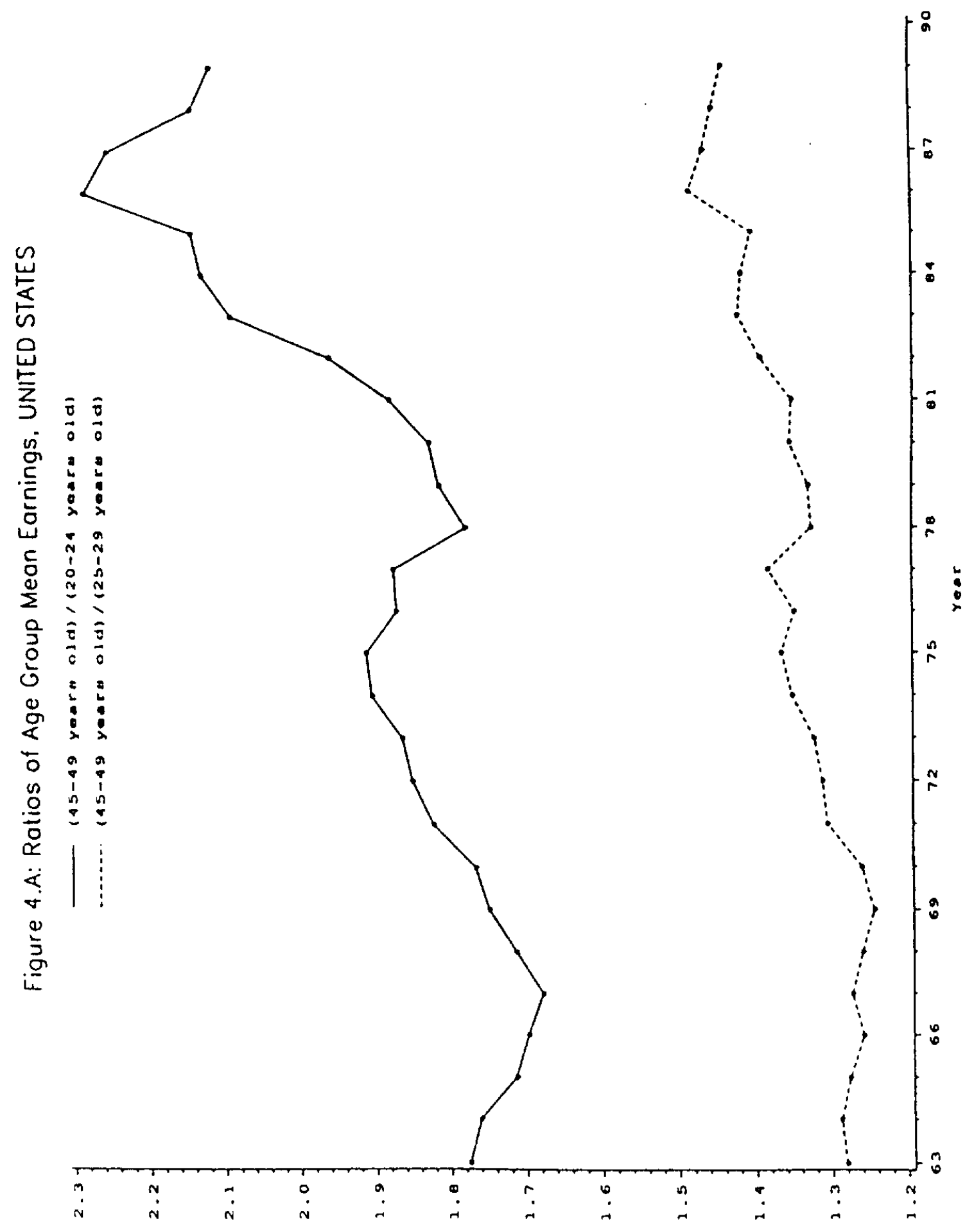




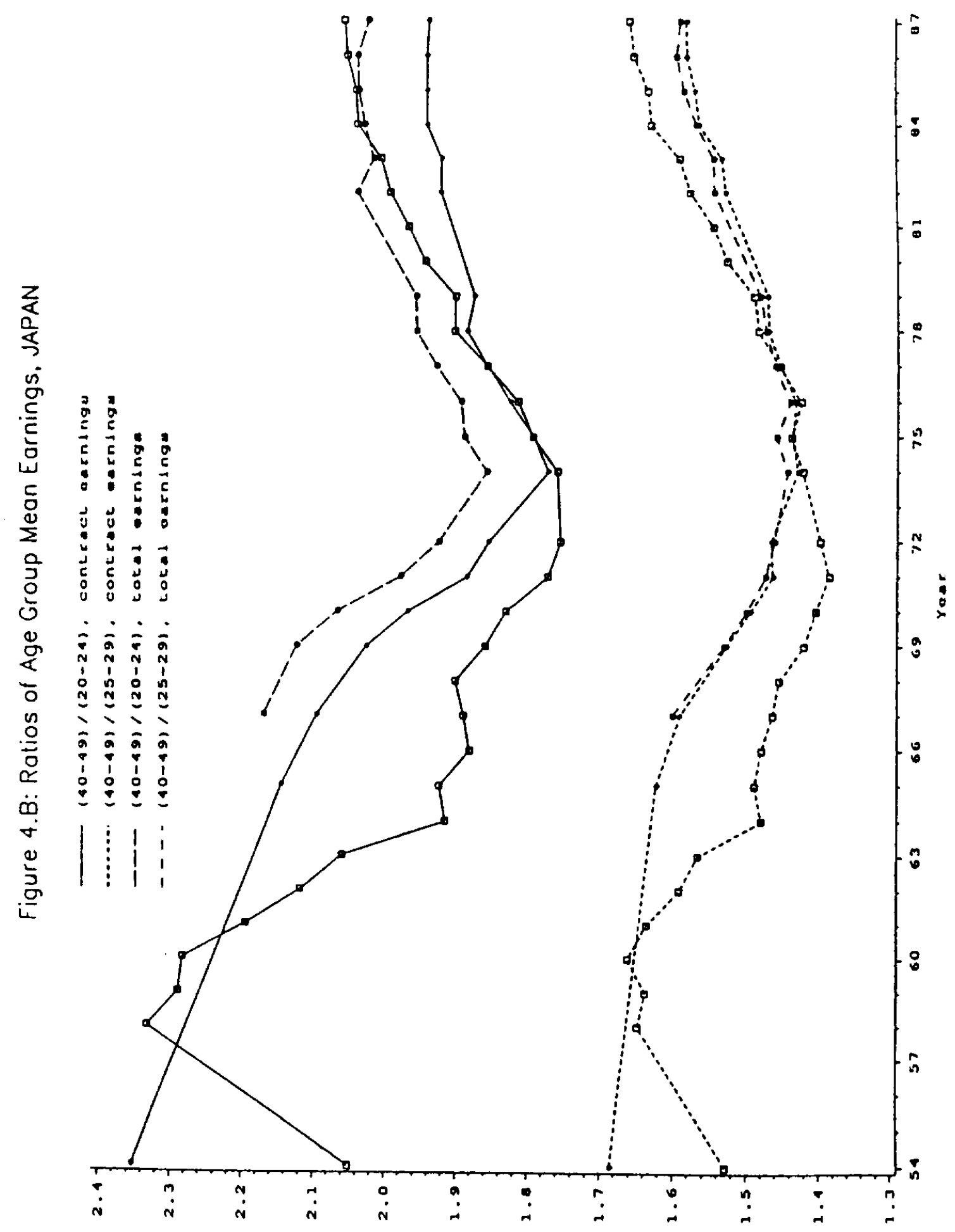




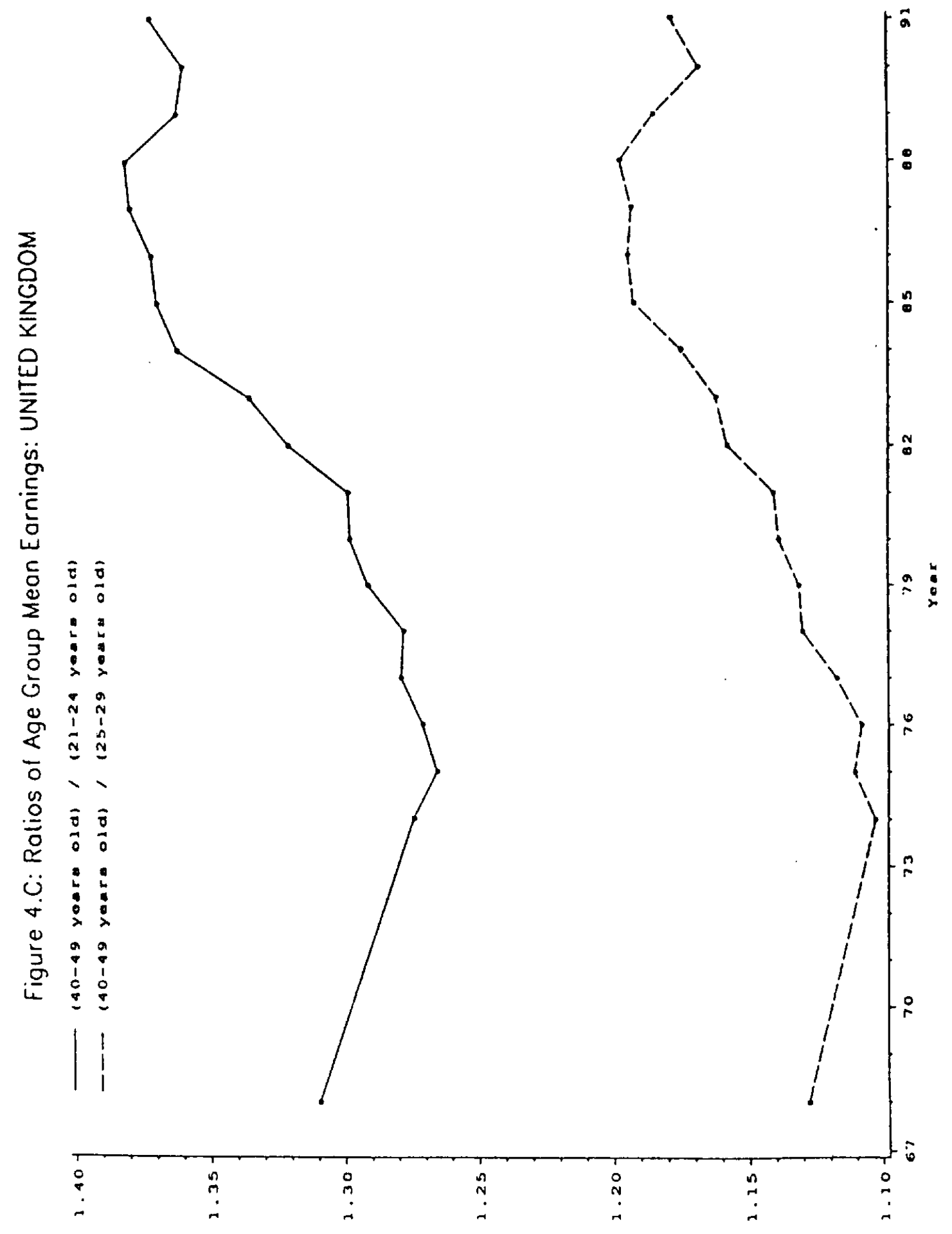




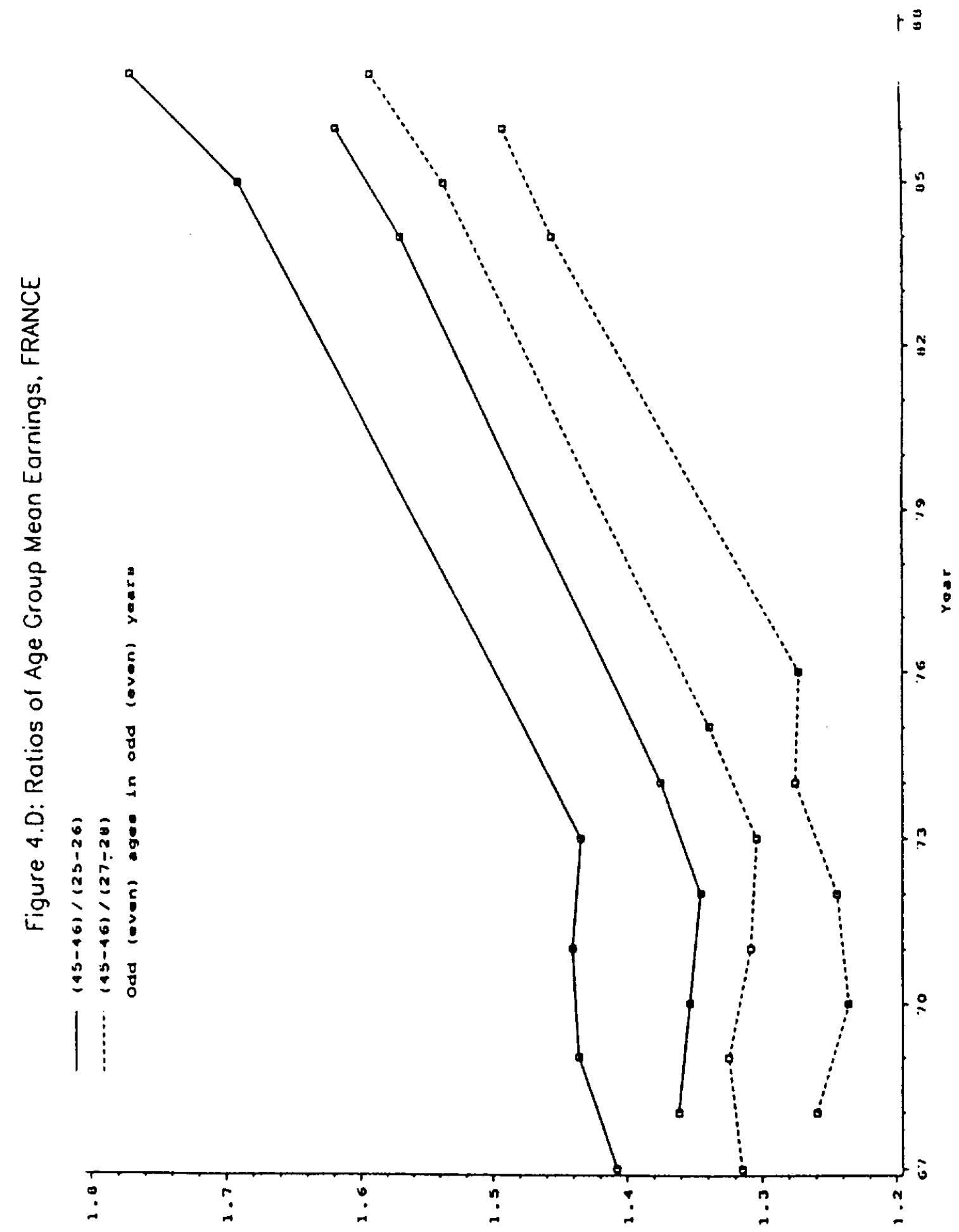




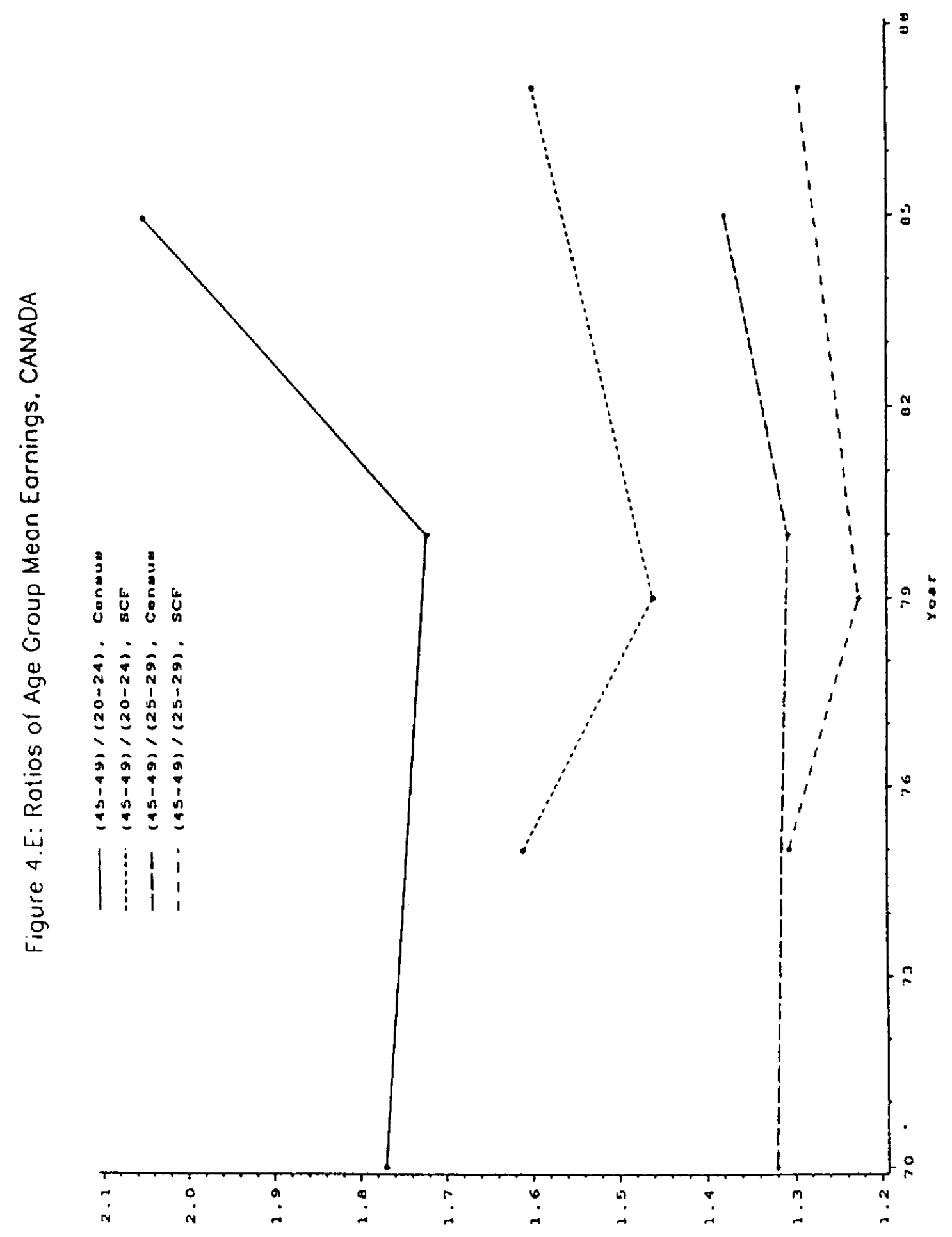




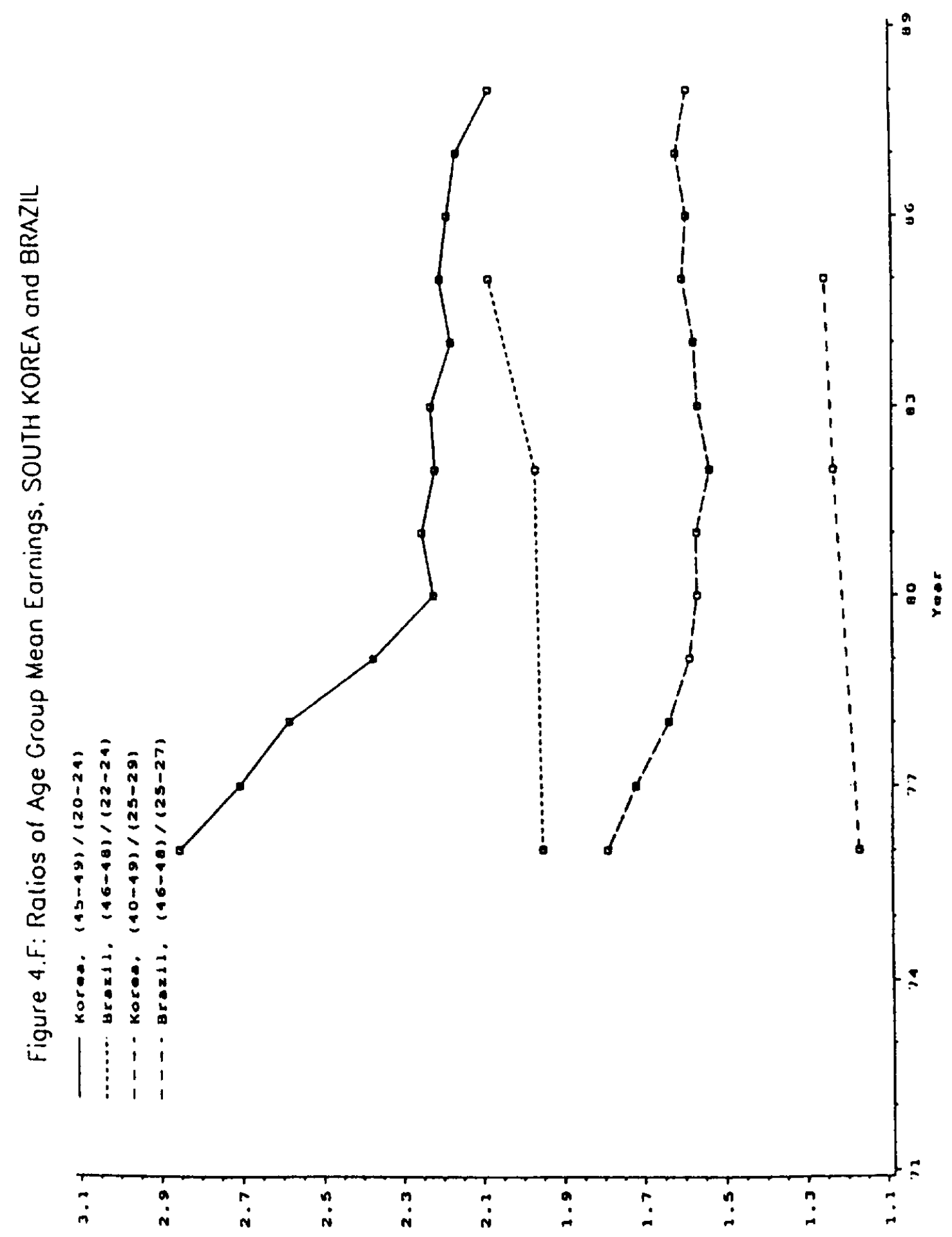




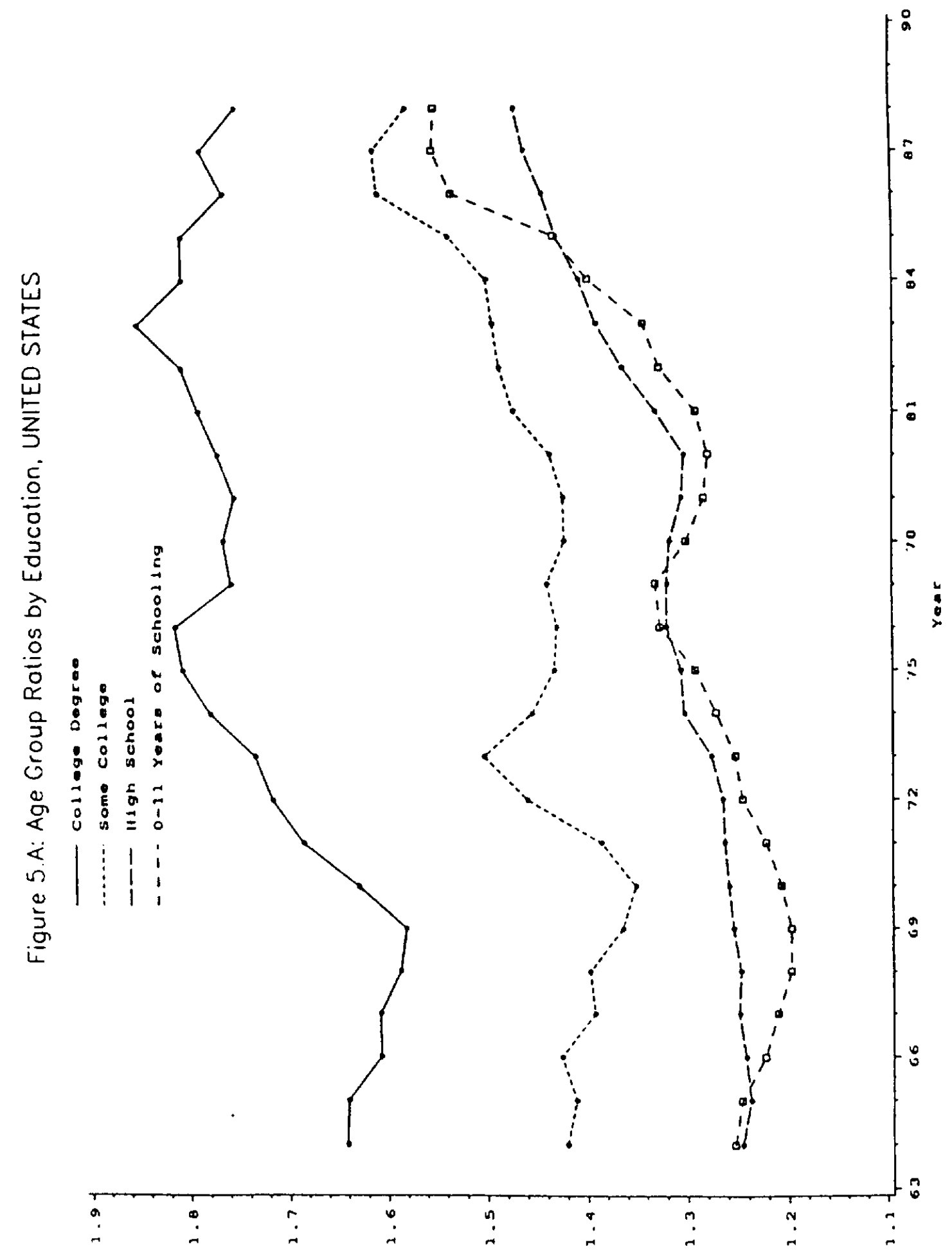




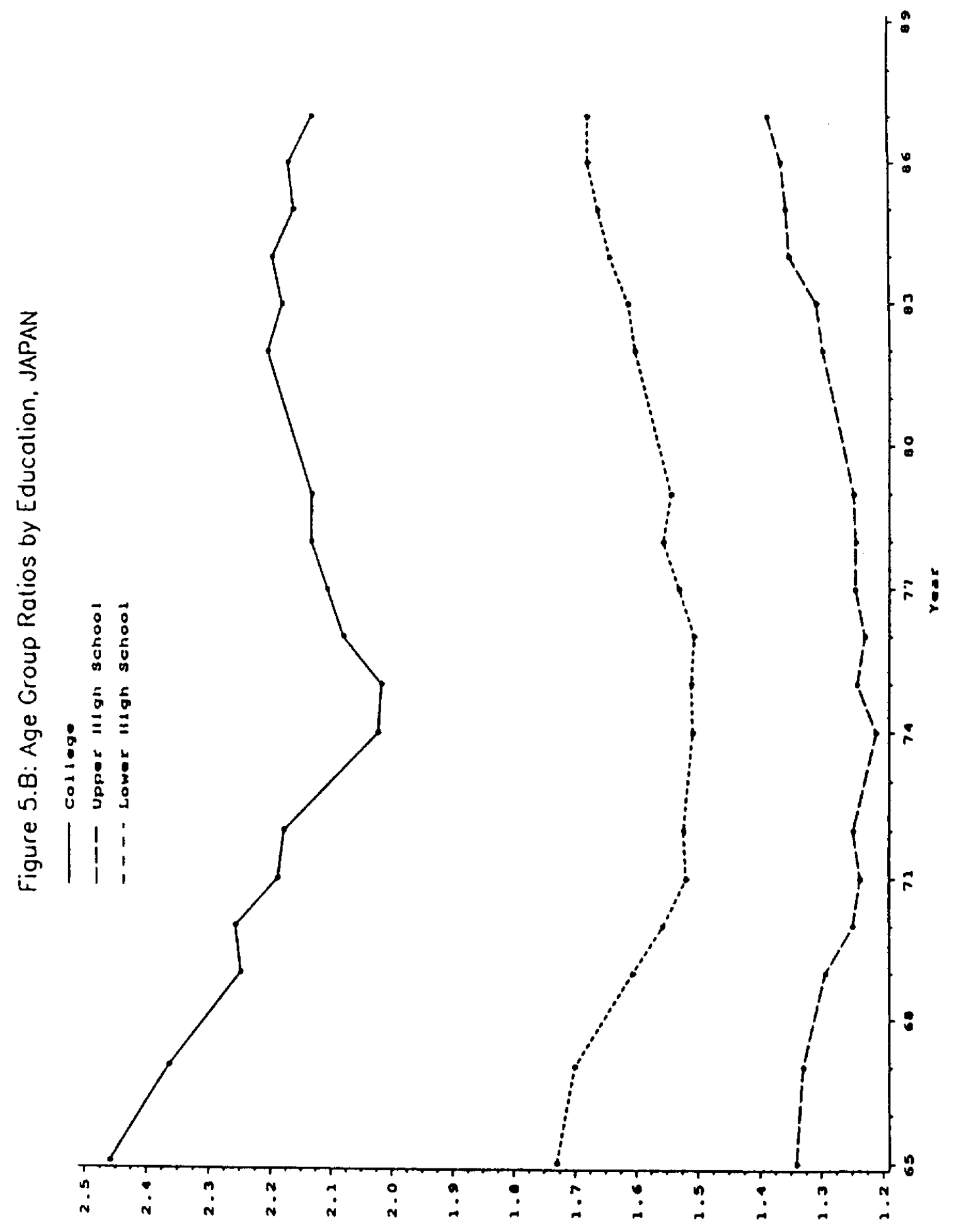




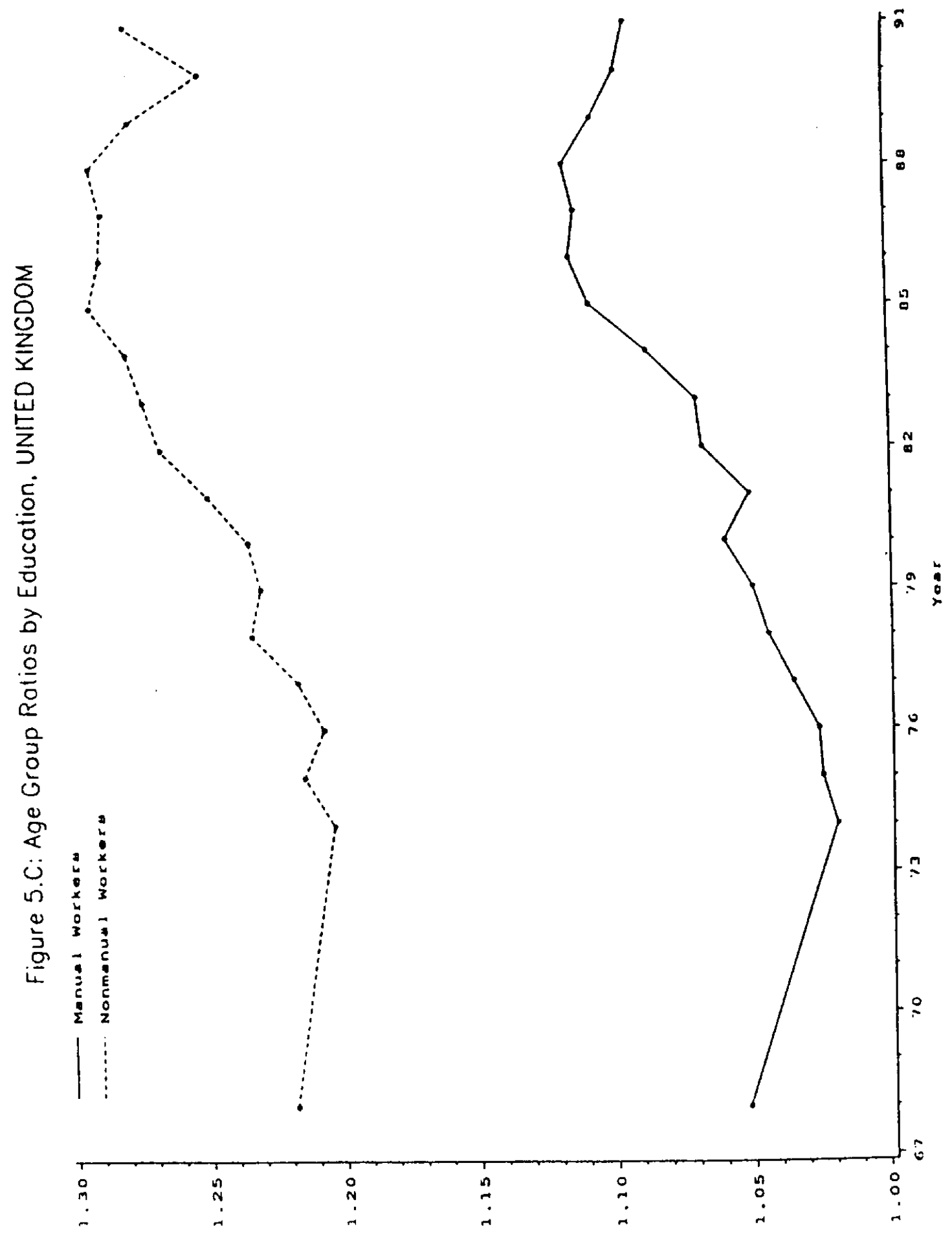




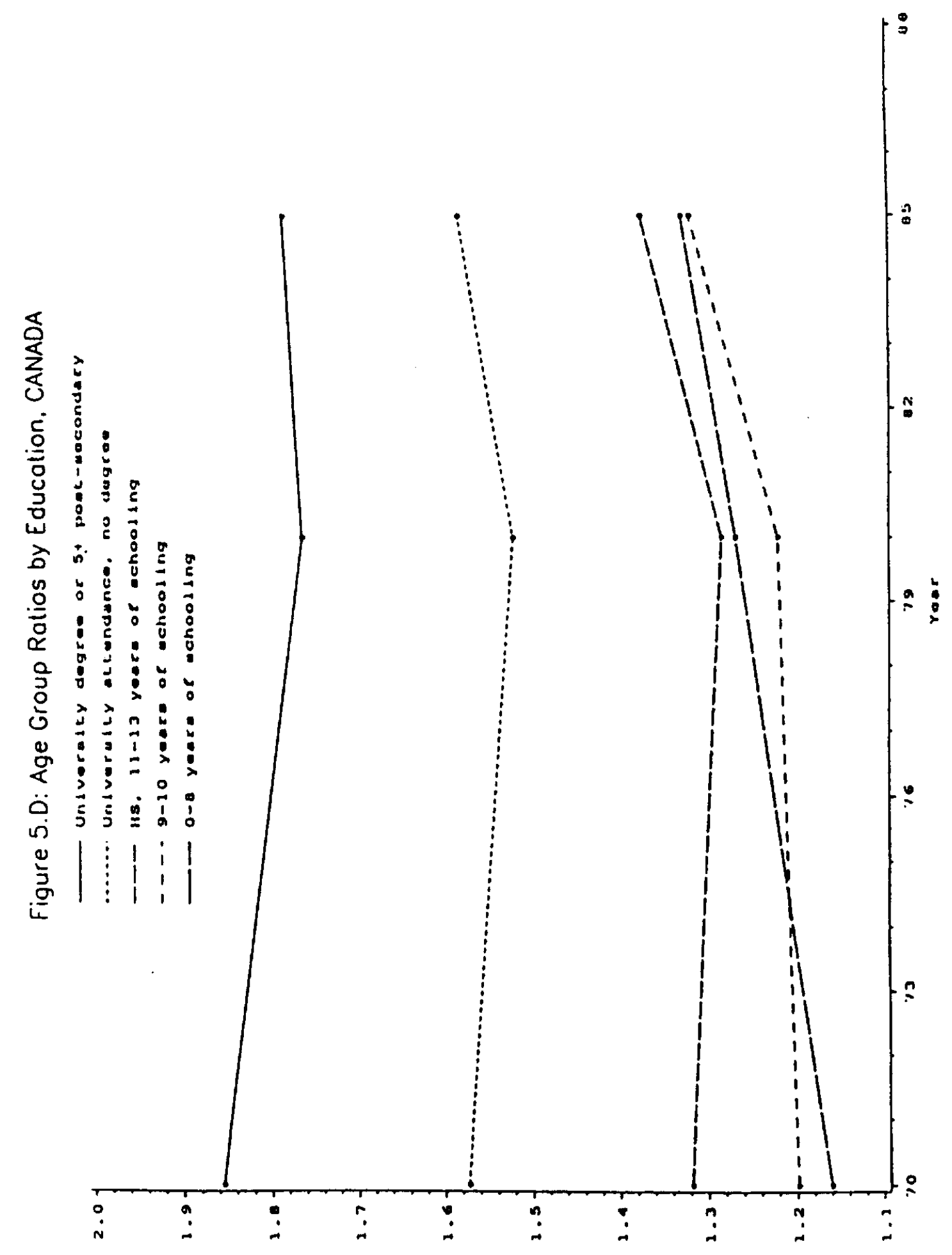




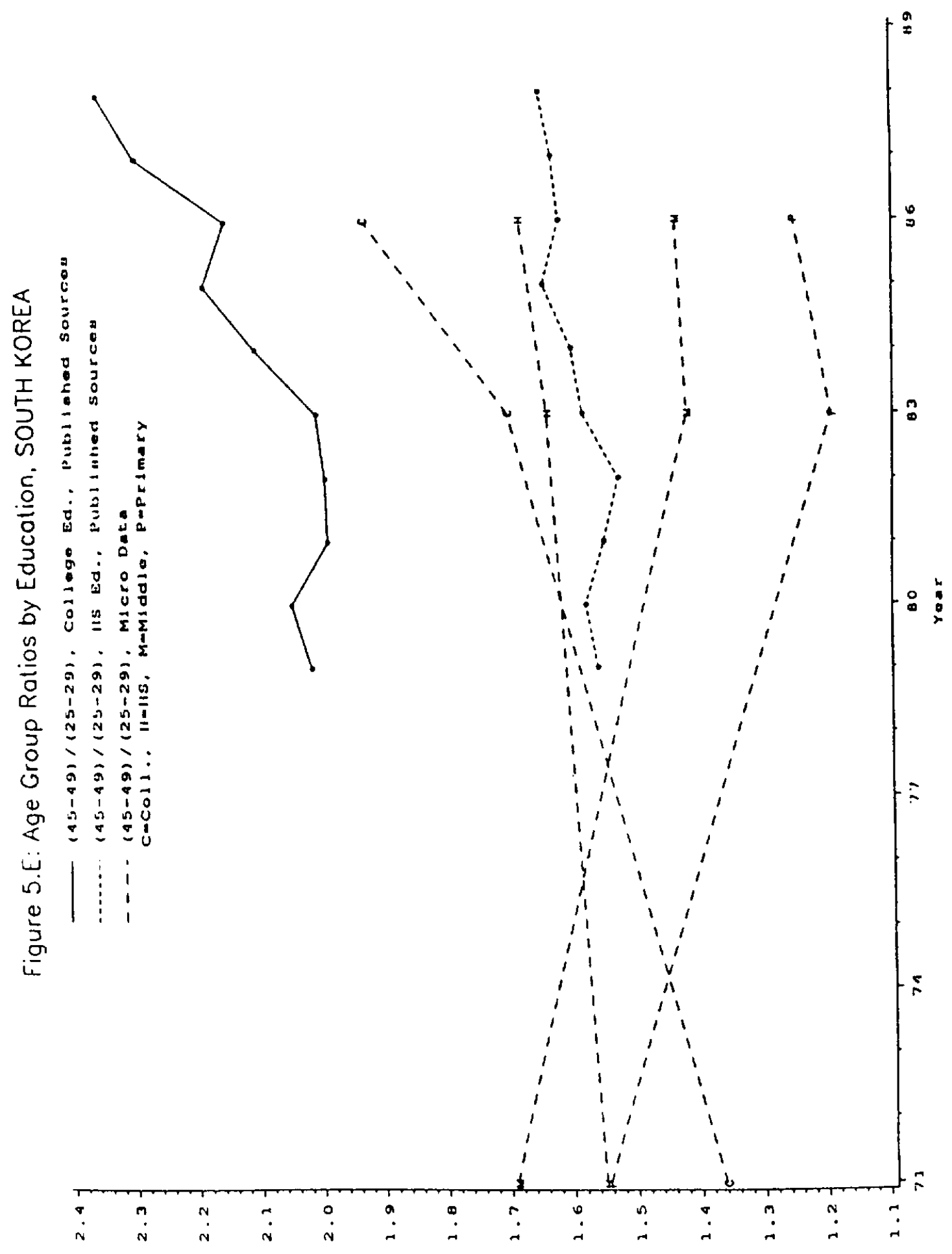




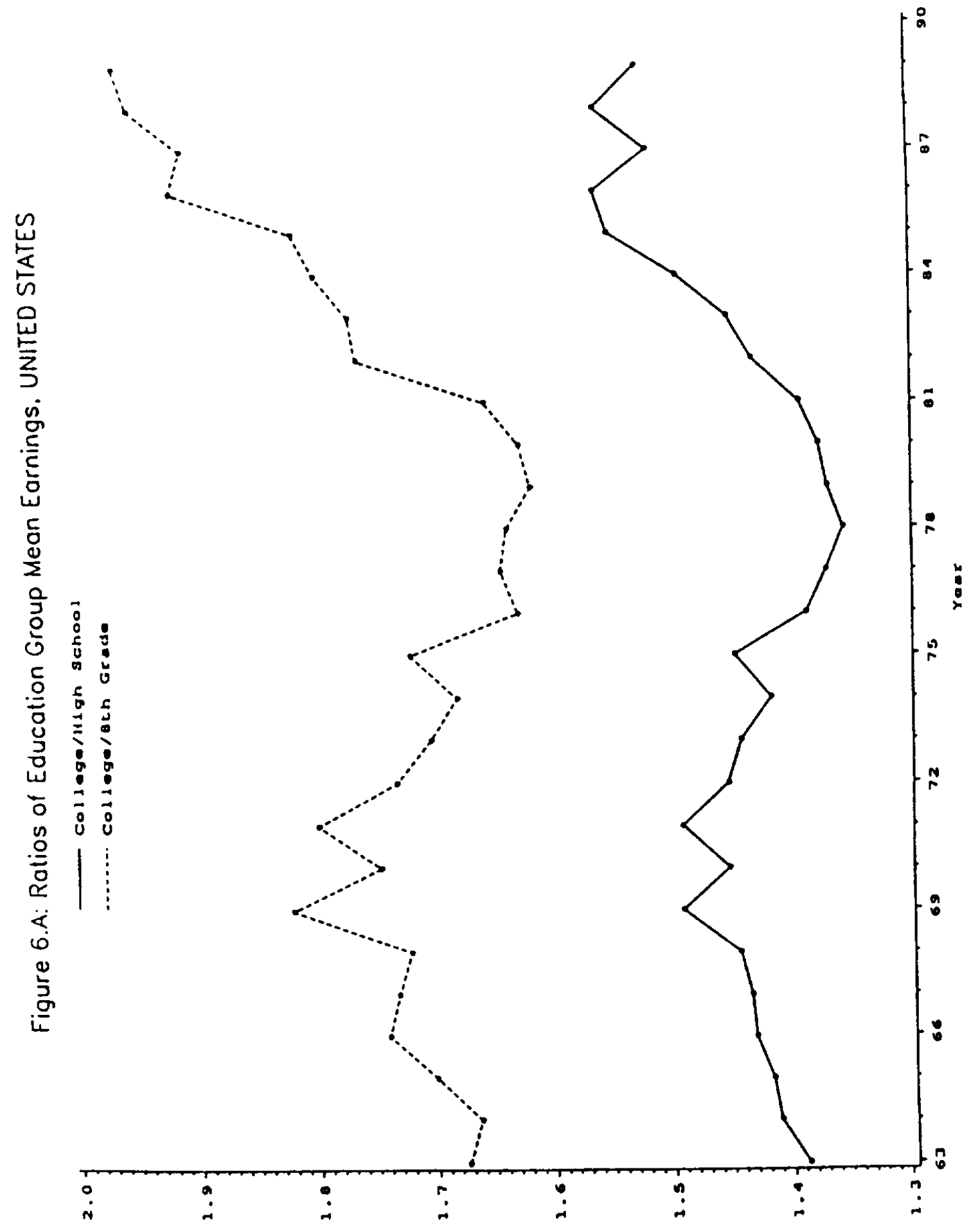




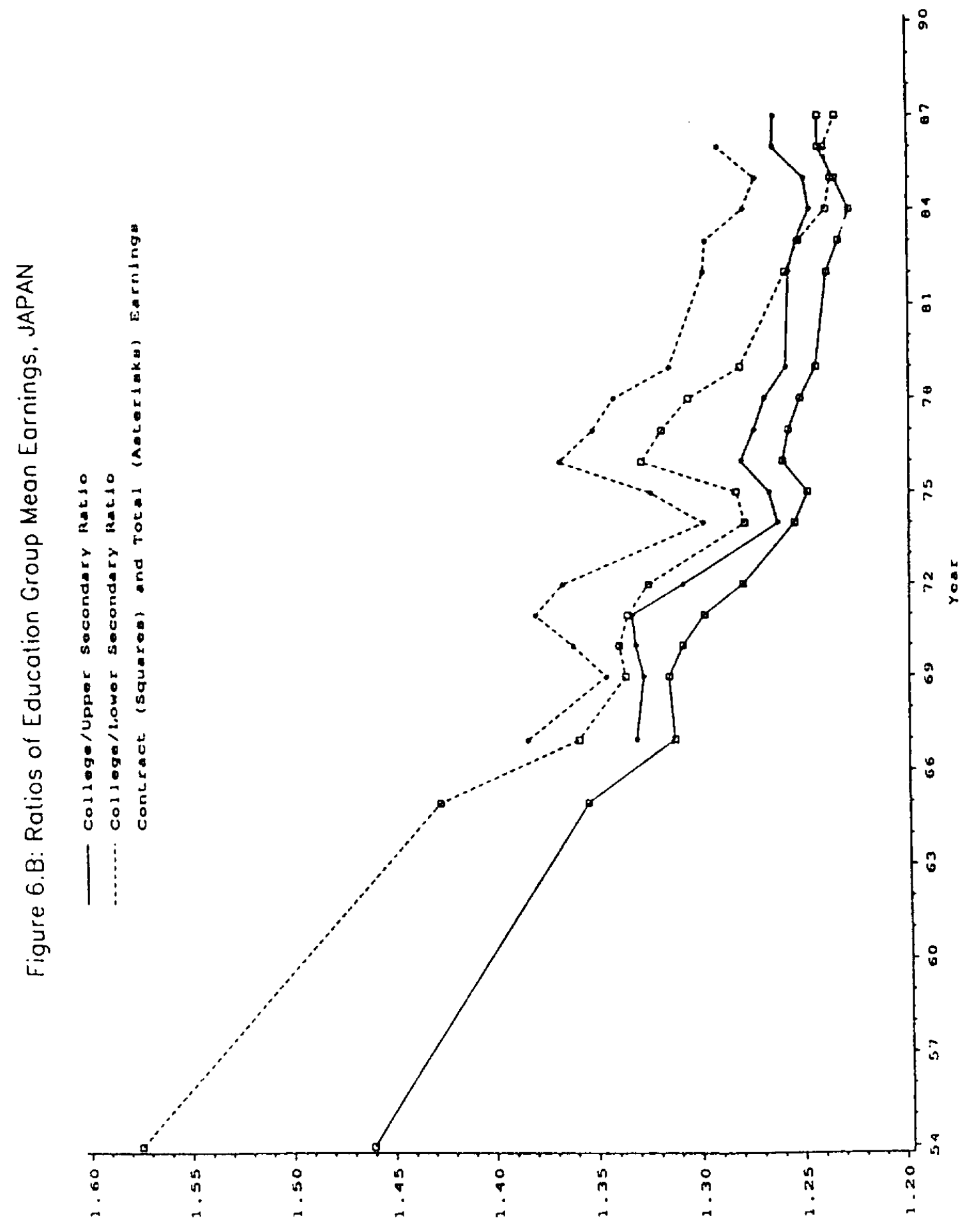



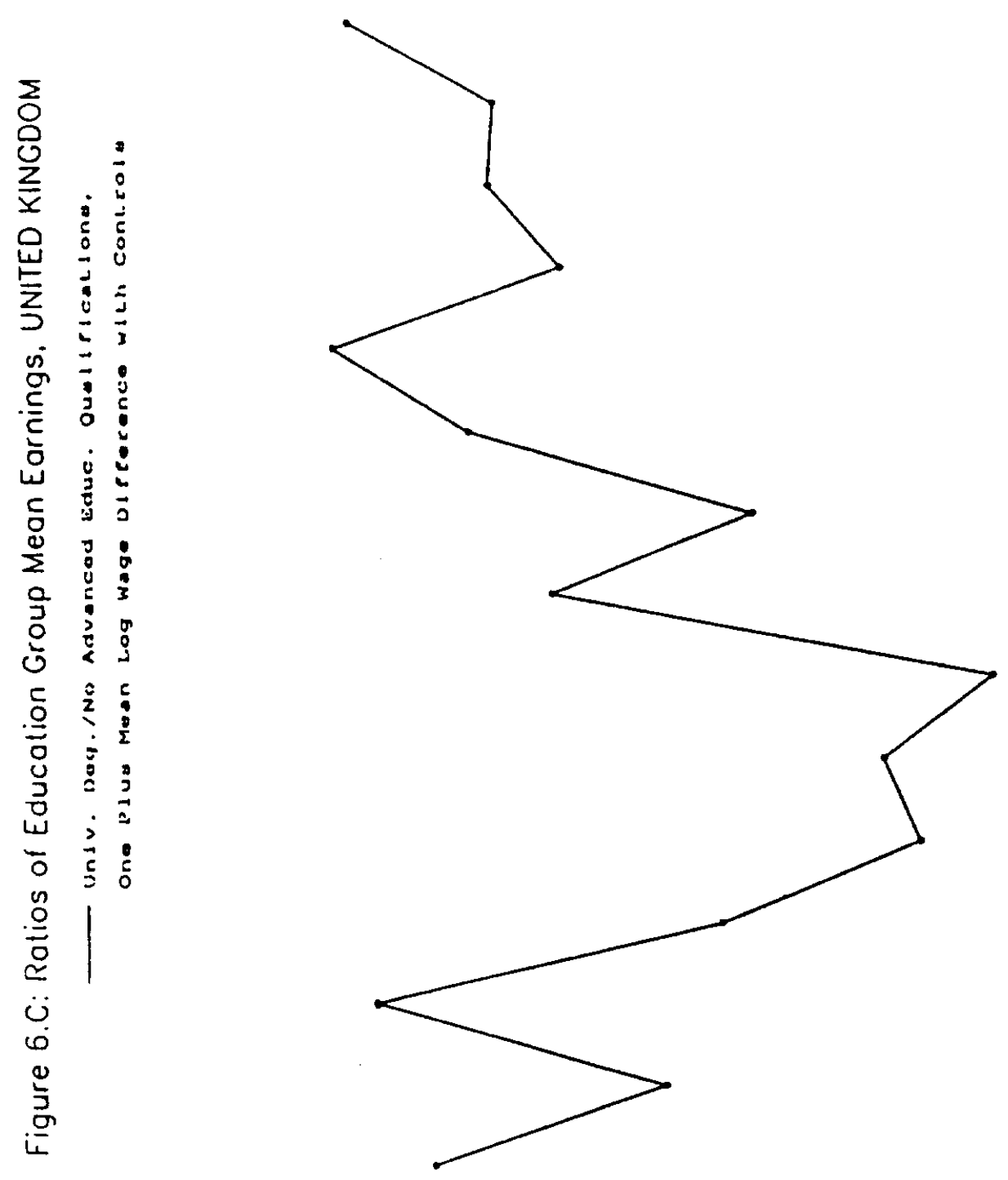

$=$

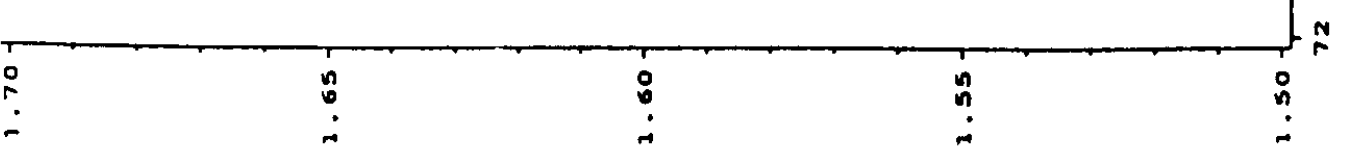




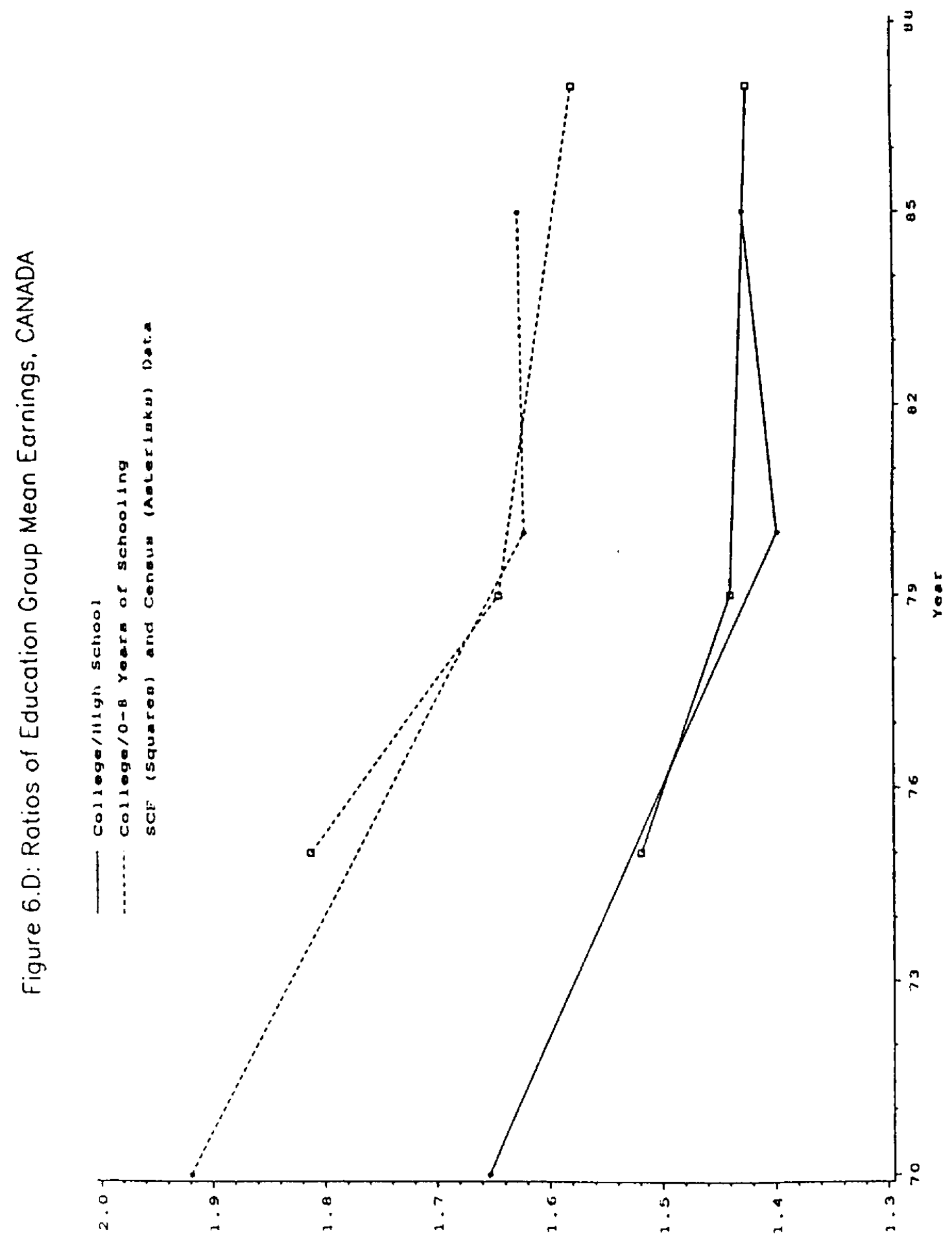



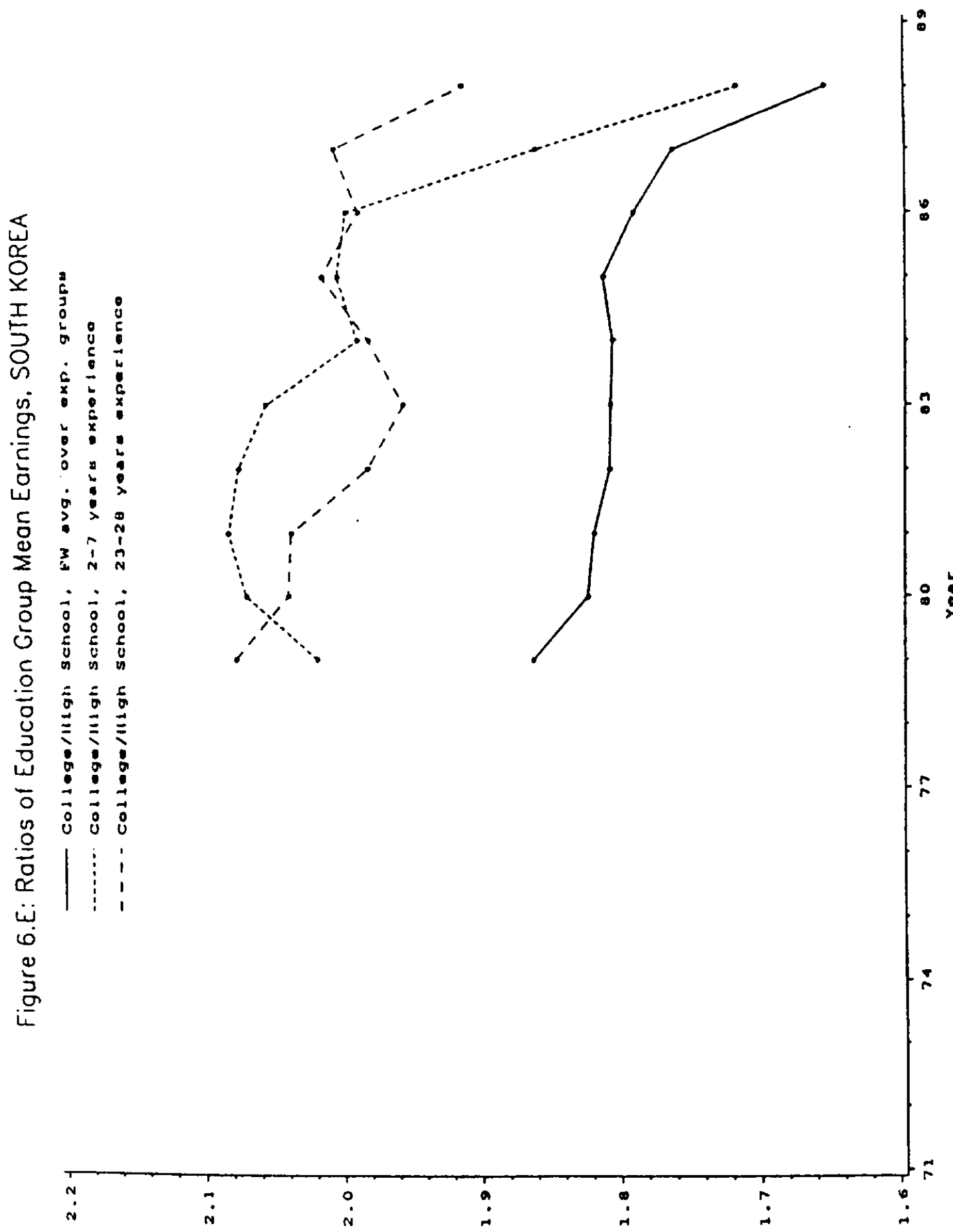


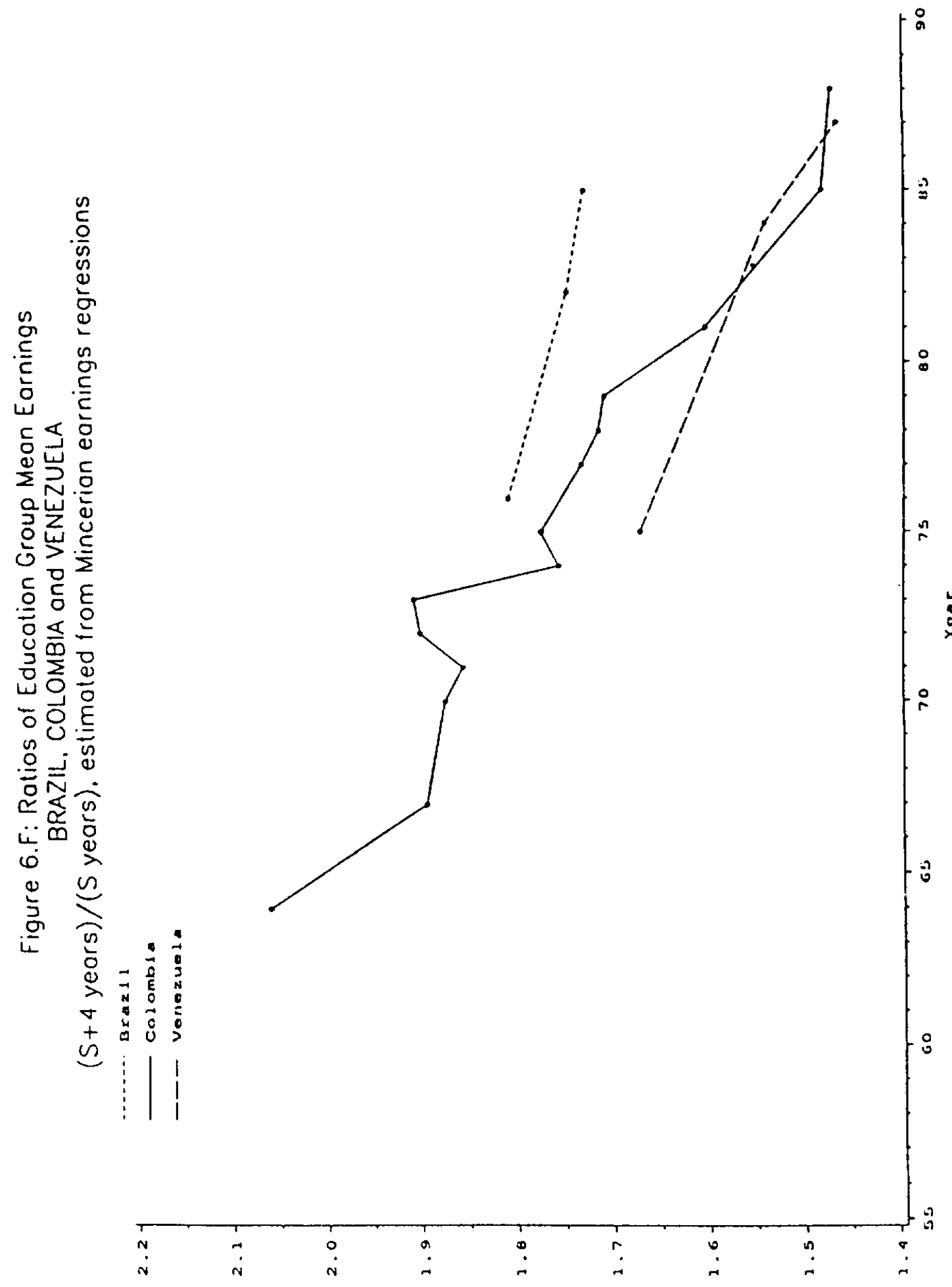




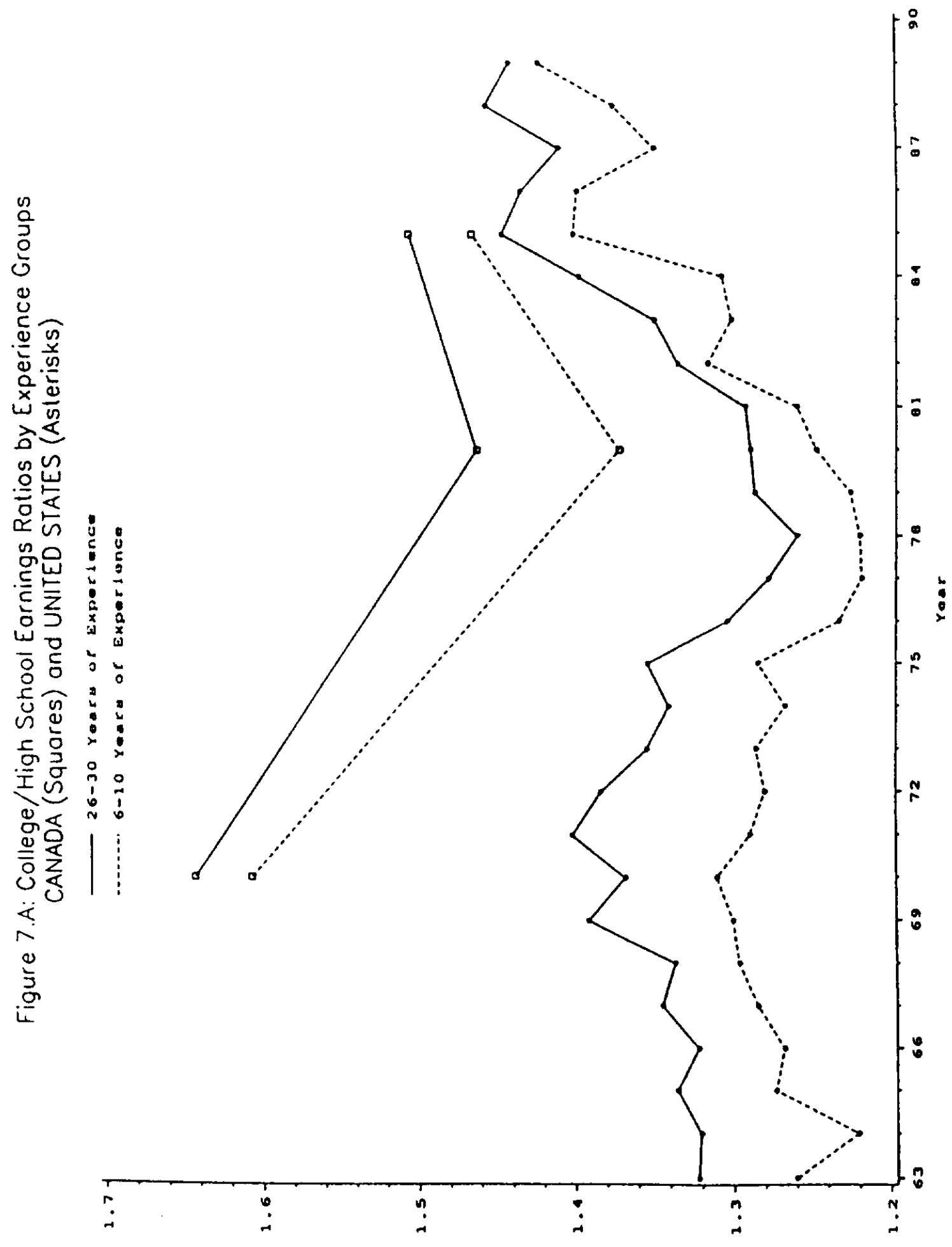




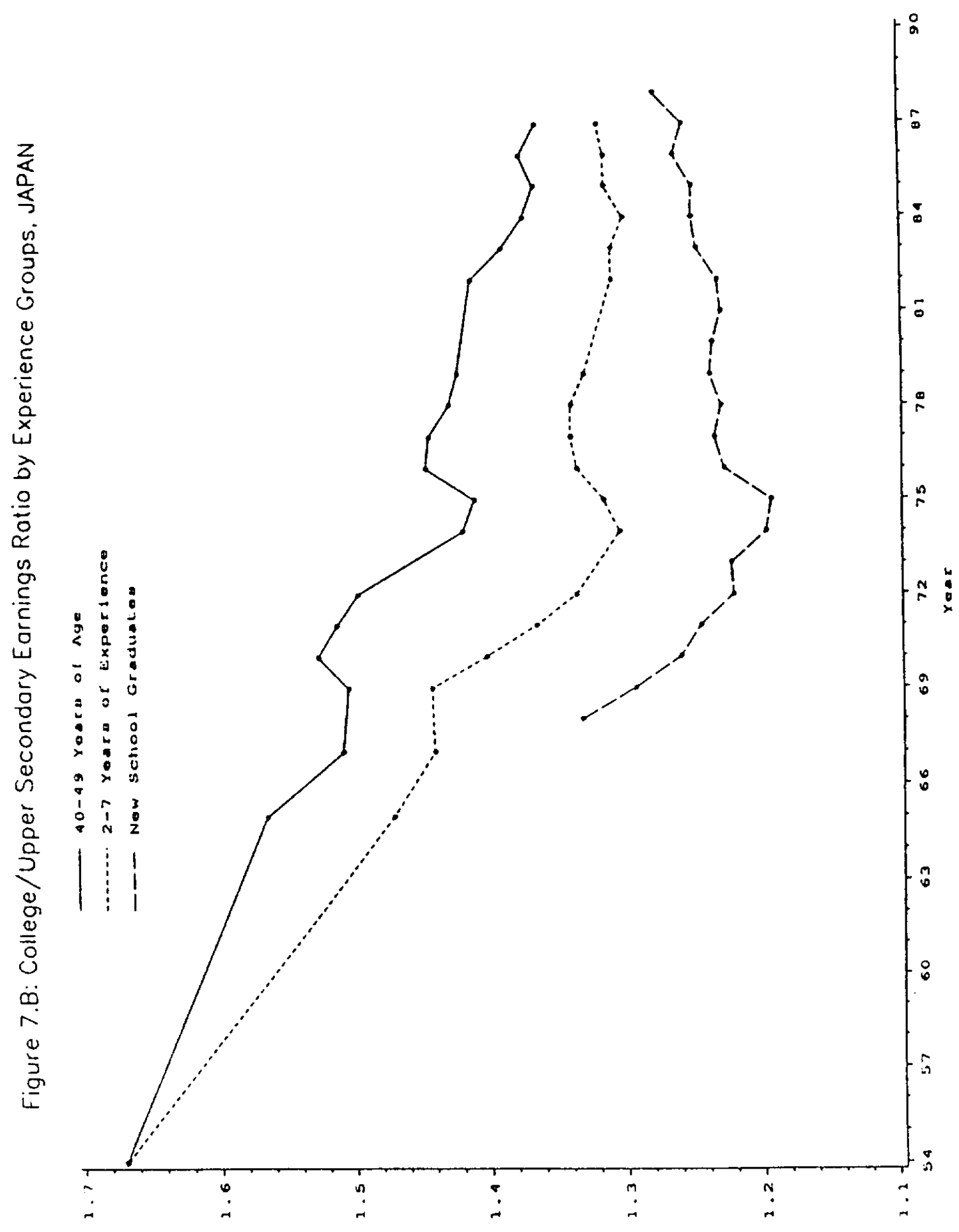




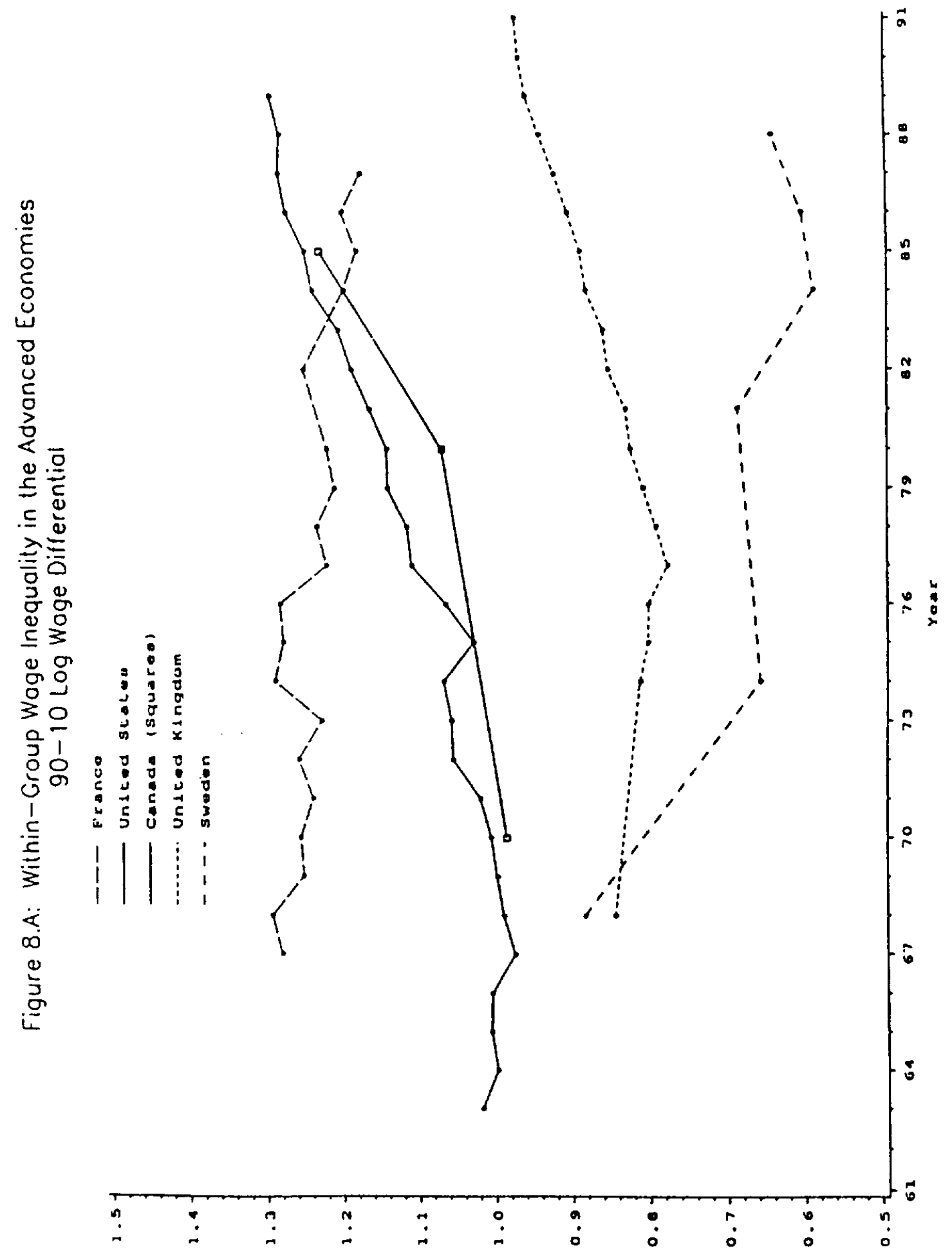




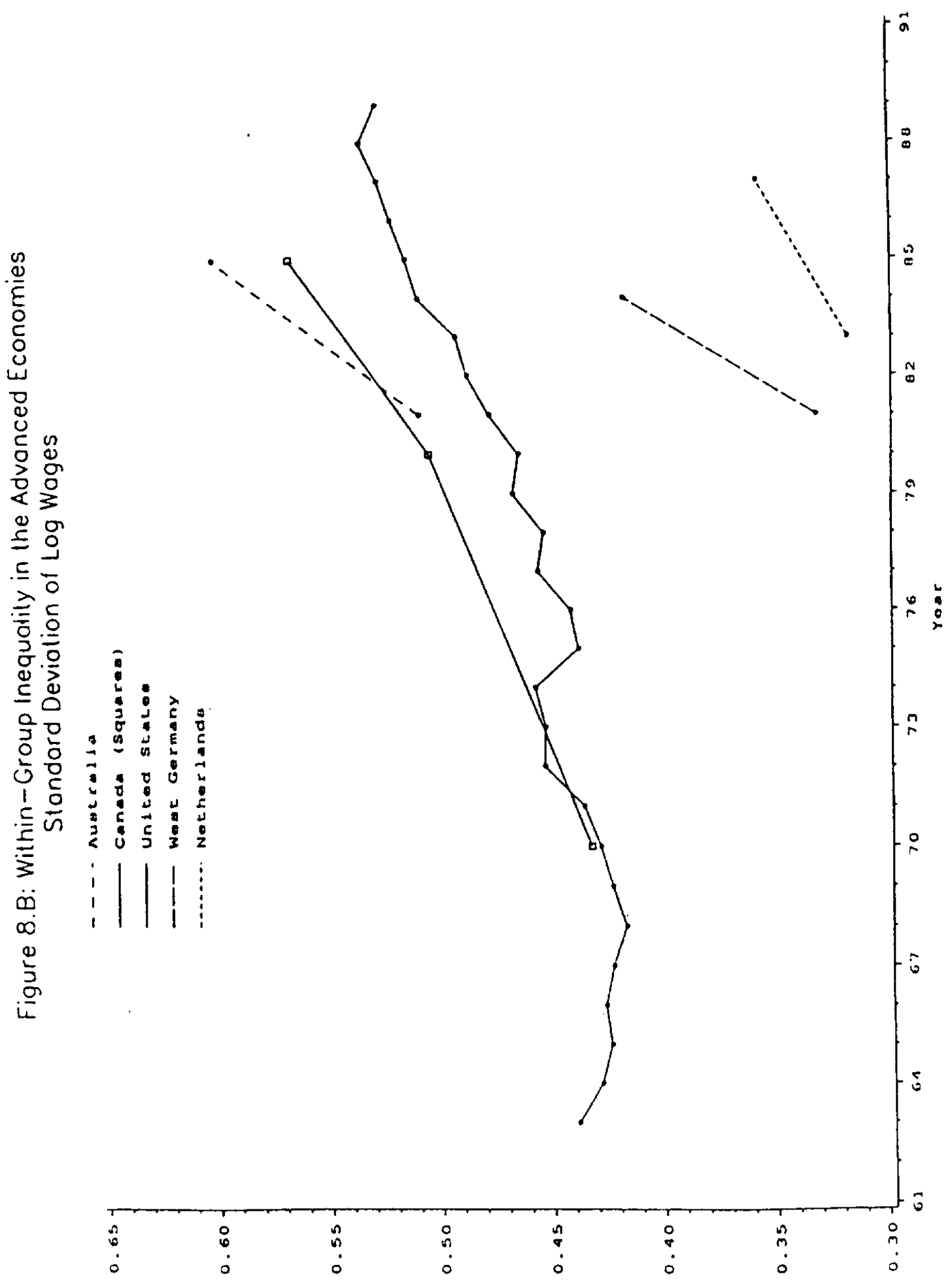




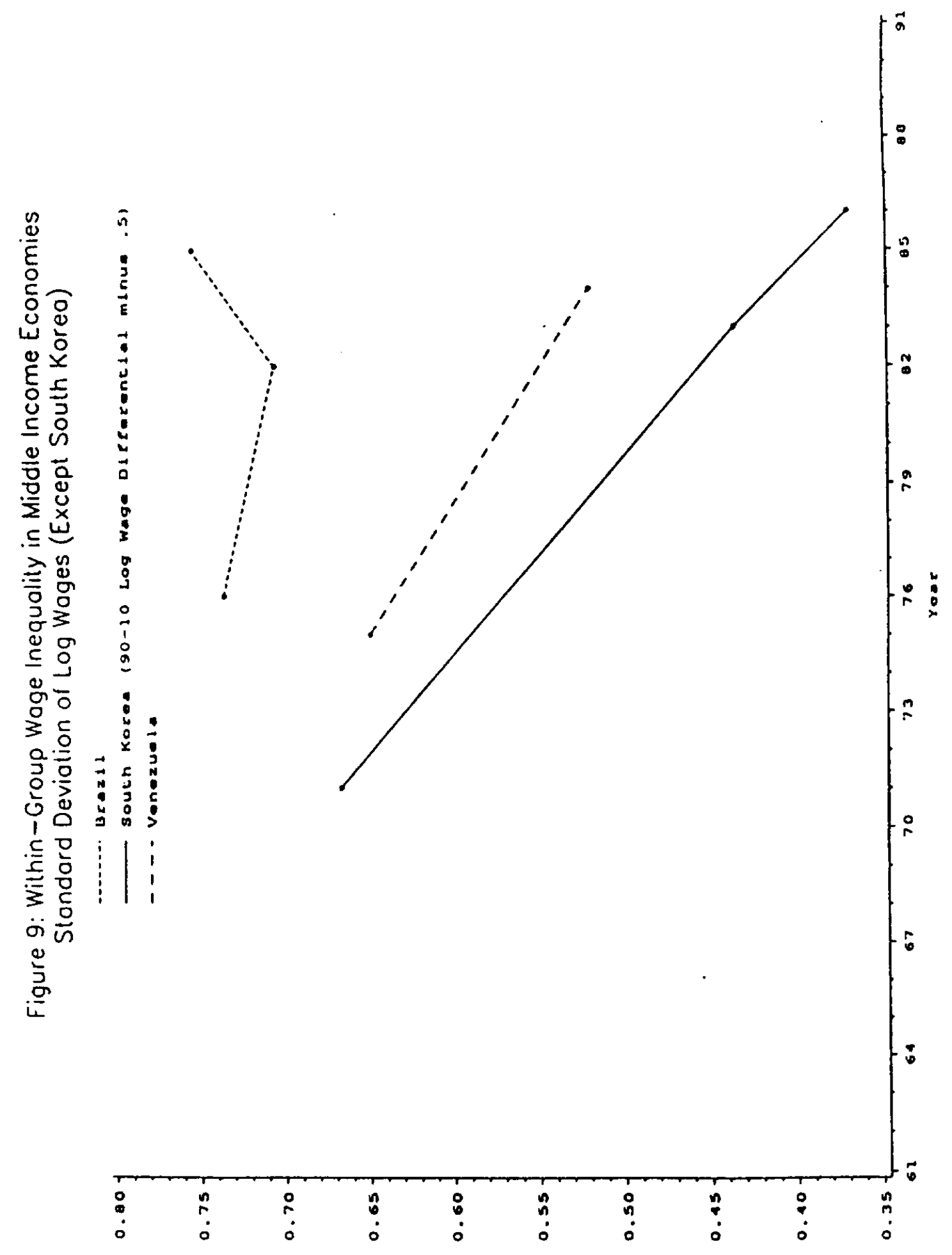




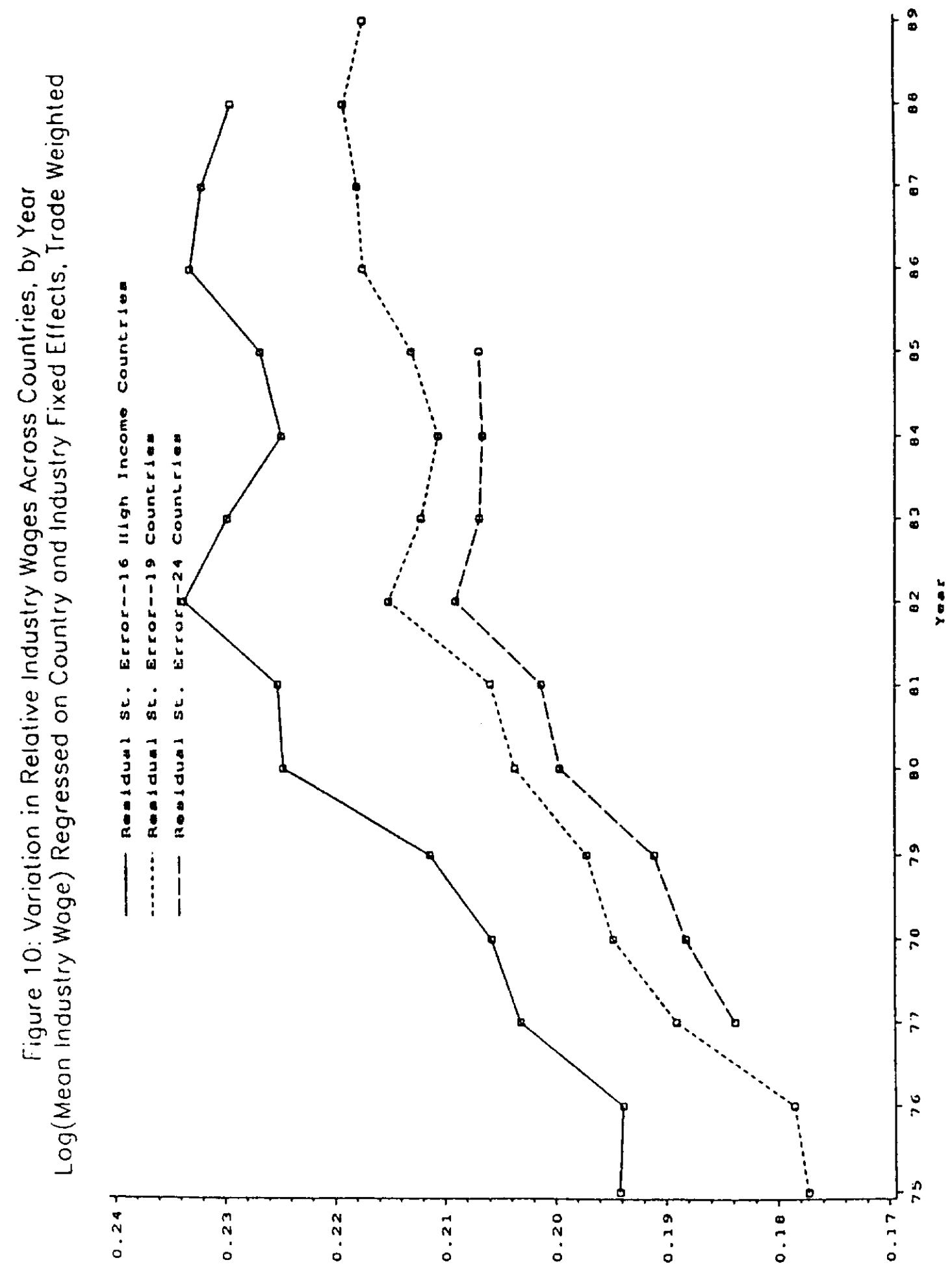




\section{NOTES TO FIGURES}

For all figures, the data source, earnings measure, and selection criteria are as described in Table 1, unless specified otherwise.

\section{Notes to Figure 4}

Squares indicate ratios of raw age group means. Asterisks indicate ratios of fixedweight average age group means. where the weights equal sample average shares of three to six education groups, as indicated below.

United States: Fixed-weight average over five education groups; weights equal average share of weeks worked during 1963-1989.

Japan: Fixed-weight average over three or four education groups; weights equal average employment shares over 1971 1.1987.

United Kingdom: Fixed-weight average over manual and nonmanual workers; weights equal to average of employment shares in $1974,1979,1984$, and 1989. The plotted values equal one plus the log ratio of age group median earnings.

Canada: Fixed-weight average over five (Census) or six (SCF) education groups; weights equal average employment shares for the three sample years for each source.

\section{Notes to Figure 5}

United States: Ratio: (45-49 years)/(25-29 years). Plotted values represent three-year moving averages.

Japan: Ratio: (40-49 years)/(25-29 years). Plotted values are for contract earnings; the corresponding series for total earnings, which begin in 1967, are very similar.

United Kingdom: Ratio: (40-49 years)/(25-29 years). Plotted values equal one plus the $\log$ ratio of age group medians.

Conada: Ratio: (45-49 years)/(25-29 years). Based on Census data.

South Korea: Ratio: (45-49 years)/(25-29 years).

\section{Notes to Figure 6}

United States: Ratio of fixed-weight averages over eight five-year experience groups; weights equal average employment shares over $1967-1989$.

Japan: Ratio of fixed-weight averages over six age groups for college-educated workers and seven age groups for less educated workers; weights equal average employment shares over 1971-1987.

Canada: Ratio of fixed-weight average nine five-year experience groups; weights equal average employment shares for the three sample years for each source.

Uniled Kingdom: Estimated log wage differential between men with a university degree and men with no advanced educational qualifications, based on OLS regressions reported by Schmitt (1991) in Table 5. The regressions control for a quadratic in experience, region, race, marital status, and presence of children. The "no advanced educational qualifications" category accounts for $54 \%$ of the male labor force in 1974 and $32 \%$ in 1988 . 
South Korea: Ratio of fixed-weight averages over six age groups for college-educated workers and seven age groups for less educated workers.

Brazil: Calcuated as $(1+\beta)^{4}$, where $\beta$ is the fixed-weight average value of the schooling coefficient in separate Mincerian eanings regressions for thirteen three-year age groups.

Venezuela: Calcuated as $(1+\beta)^{4}$, where $\beta$ is the schooling coefficient in a Mincerian eanings regression that controls for log hours worked and a quadratic in experience.

Colombia: Calculated as $(1+\beta)^{4}$, where $\beta$ is the schooling coefficient from a Mincerian earnings regression (unspecified control set).

\section{Notes to Figures 8 and 8}

All standard deviation statistics represent the square root of a weighted mean of within-group log variances.

United States: Fixed-weight averageover seven education groups by eight experience groups;

France: Equal-weight average over single-year age groups for men aged 31 to 48 ; odd ages in odd years and even ages in even years.

United Kingdom: Fixed-weight average over seven age groups by two occupation groups.

Canada: Fixed-weight average over five education groups by nine experience groups; based on the Census.

Sweden: Fixed-weight average over five education groups.

A ustralia: Equal-weight average over three education groups.

West Germany: Equal-weight average over three education groups.

Netherlands: Equal-weight average over three education groups.

Brazil: Fixed-weight average over thirteen age groups of the standard deviation of log wage residuals in a Mincerian earnings regression. The age-group specific regressions control for years of schooling and hours worked.

South Korea: Fixed-weight average over four education groups by eight experience groups.

Venezuela: The standard deviation of log wage residuals in a Mincerian earnings regression that controls for hours worked, years of schooling and a quadratic in experience. 